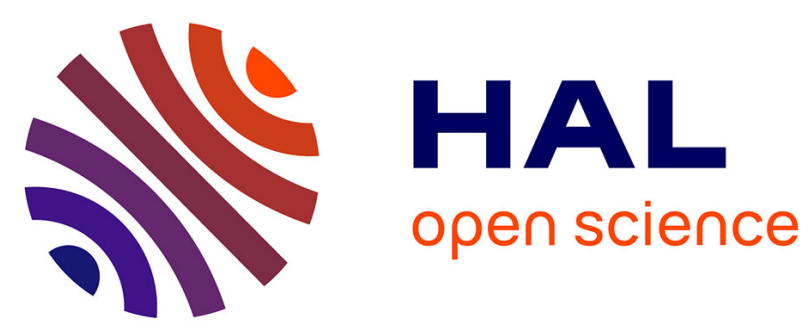

\title{
Acclimation capacity of the three-spined stickleback (Gasterosteus aculeatus, L.) to a sudden biological stress following a polymetallic exposure
}

Antoine Le Guernic, Wilfried Sanchez, Olivier Palluel, Anne Bado-Nilles, Magali Floriani, Cyril Turies, Edith Chadili, Claire Della-Vedova, Isabelle Cavalie, Christelle Adam-Guillermin, et al.

\section{To cite this version:}

Antoine Le Guernic, Wilfried Sanchez, Olivier Palluel, Anne Bado-Nilles, Magali Floriani, et al.. Acclimation capacity of the three-spined stickleback (Gasterosteus aculeatus, L.) to a sudden biological stress following a polymetallic exposure. Ecotoxicology, 2016, 25 (8), pp.1478-1499. 10.1007/s10646016-1699-6 . ineris-01863105

\section{HAL Id: ineris-01863105}

https://hal-ineris.archives-ouvertes.fr/ineris-01863105

Submitted on 28 Aug 2018

HAL is a multi-disciplinary open access archive for the deposit and dissemination of scientific research documents, whether they are published or not. The documents may come from teaching and research institutions in France or abroad, or from public or private research centers.
L'archive ouverte pluridisciplinaire HAL, est destinée au dépôt et à la diffusion de documents scientifiques de niveau recherche, publiés ou non, émanant des établissements d'enseignement et de recherche français ou étrangers, des laboratoires publics ou privés. 
Acclimation capacity of the three-spined stickleback (Gasterosteus aculeatus, L.) to a sudden biological stress following a polymetallic exposure.

\title{
Authors
}

Antoine Le Guernic ${ }^{1,2,3^{*}}$,Wilfried Sanchez ${ }^{1}$, Olivier Palluel ${ }^{1}$, Anne Bado-Nilles ${ }^{1}$, Magali Floriani $^{2}$, Cyril Turies ${ }^{1}$, Edith Chadili ${ }^{1}$, Claire Della Vedova ${ }^{2}$, Isabelle Cavalié ${ }^{2}$, Christelle Adam-Guillermin ${ }^{2}$, Jean-Marc Porcher ${ }^{1}$, Alain Geffard ${ }^{3}$, Stéphane Betoulle ${ }^{3}$, Béatrice Gagnaire $^{2}$.

${ }^{1}$ Institut National de l'Environnement Industriel et des Risques (INERIS), UMR-I 02 SEBIO (Stress Environnementaux et Biosurveillance des milieux aquatiques), BP 2, 60550 Verneuilen-Halatte, France.

${ }^{2}$ Institut de Radioprotection et de Sûreté Nucléaire (IRSN), PRP-ENV/SERIS/LECO, Centre de Cadarache, 13115 Saint-Paul-lez-Durance, France.

${ }^{3}$ Université de Reims Champagne-Ardenne (URCA), UMR-I 02 SEBIO, UFR Sciences Exactes et Naturelles, Campus Moulin de la Housse, B.P. 1039, 51687 Reims, France.

*Corresponding author: antoineleguernic@gmail.com, phone: +33 650091650.

\begin{abstract}
To get closer to the environmental reality, ecotoxicological studies should no longer consider the evaluation of a single pollutant, but rather combination of stress and their interaction. The aim of this study was to determine if responses of a fish to a sudden biological stress could be modified by a prior exposure to a chemical stress (a polymetallic contamination). For this purpose, in situ experiment was conducted in three ponds in the Haute-Vienne department (France). One pond was chosen for its high uranium concentration due to uranium mine tailings, and the two other ponds, which were not submitted to these tailings. Three-spined sticklebacks (Gasterosteus aculeatus) were caged in these ponds for 14 days. After this period, fish were submitted to a biological stress, exerted by lipopolysaccharides injection after anesthesia, and were sacrificed four days after these injections for multi-biomarkers analyses (leucocyte viability, phagocytic capacity and reactive oxygen species production, antioxidant peptide and enzymes, lipid peroxidation and DNA damage). The pond which received uranium mine tailings had higher metallic concentrations. Without biological stress,
\end{abstract}


sticklebacks caged in this pond presented an oxidative stress, with increasing of reactive oxygen species levels, modification of some parts of the antioxidant system, and lipid peroxidation. Caging in the two most metal-contaminated ponds resulted in an increase of susceptibility of sticklebacks to the biological stress, preventing their phagocytic responses to lipopolysaccharides and modifying their glutathione contents and glutathione-S-transferase activity.

\section{Keywords}

Acclimation capacity; polymetallic contamination; lipopolysaccharides; chemical stress; biological stress; caging; three-spined stickleback. 


\section{Introduction}

Metals, or trace metals, are certainly the most studied class of pollutants during the last century by toxicologists. All metals, including essential trace metals, are potentially hazardous at high concentrations for organisms, including fish (Förstner and Wittmann 2012; Sindayigaya et al. 1994). Metals induce an oxidative stress, by influencing reactive oxygen species (ROS) production (Ferreira et al. 2008; Sanchez et al. 2005; Sevcikova et al. 2011). For the protection against ROS, organisms can set up their antioxidant system. This system includes several enzymes, proteins and peptides produced by the liver, and their aim is to neutralize ROS (Eyckmans et al. 2011; Heier et al. 2013; Kelly and Janz 2009; Sanchez et al. 2005). The antioxidant system may also be altered by pollutants and in particular metals (Fernandez-Davila et al. 2012; Oliva et al. 2012; Qu et al. 2014). ROS can cause damage in fish, such as DNA damage, lipid peroxidation, tissue injuries (Almroth et al. 2008; Stadtman and Oliver 1991). Metals can also suppress or stimulate the immune system (Bols et al. 2001; Dunier 1996; Jolly et al. 2014; Zelikoff 1993). Almost all metals are found naturally in the Earth's crust, and a part of their toxicity for living organisms is due to their uses for human industries (Kelly and Janz 2009; Maceda-Veiga et al. 2013). Indeed, they were extracted, modifying their proportion in the different biosphere compartments and their chemical properties, making them soluble or able to cross biological membranes (Playle 1998; Spry and Wiener 1991). This is the case of uranium, essential actinide for the nuclear industry, which has been extracted in large quantities from the Earth's crust. In France, its extraction lasted over than half a century and focused in the Limousin region (IRSN 2007). Even after the end of uranium extraction, this metal is still found in former uranium mining sites with nonnegligible quantities, accompanied by metals naturally present or introduced during site rehabilitation (Gagnaire et al. 2015; Herlory et al. 2013).

Even if consequences on organisms of a metal exposure are well known by ecotoxicologists, it is now important to take in consideration that these organisms are exposed to a multipollution rather than a mono-pollution. Indeed, the multi-stress context is indicative of the environmental reality because the aquatic animals, including fish, are rarely exposed to a single source of stress (Lorin-Nebel et al. 2013; Maceda-Veiga et al. 2013). Although ecotoxicological studies of a single stress are necessary, the effects on aquatic fauna may vary if this pressure is in combination with one or more other stress (Chou et al. 1999; Ingram 1980; Lorin-Nebel et al. 2013). Responses and process established by an organism (acclimation capacities) against a stress, thus its susceptibility to this stress, could be modified by an exposure to another stress (Chou et al. 1999; Knittel 1981; Robohm 1986). 
Immune capacities are essential defenses against biological stress, such as bacteria, viruses or parasites, preventing the development of diseases (Bols et al. 2001; Ingram 1980). A pollutant affecting this defense system can be harmful, especially when organisms are exposed to a biological stress, can increase their susceptibility to this stress, and can even result in the death of the organism (Bols et al. 2001; Brousseau et al. 1997; Dunier 1996).

The aim of this study was to determine if a prior exposure to a metallic pollution due to a former uranium mining site (chemical stress) can modify acclimation capacities, and thus susceptibility of a fish to a sudden biological stress.

This in situ experiment was performed using the three-spined sticklebacks. These fish are present in French aquatic ecosystems (Münzing 1963) and the temperature range at which the stickleback can live corresponds to the temperature found in the Haute-Vienne ponds (Allen and Wootton 1982). Finally, its small size facilitates its handling and caging, and its robustness has led to its frequent use in environmental and ecotoxicological studies (Pottinger et al. 2002; Sanchez et al. 2008a; Sanchez et al. 2008b). These advantages were the reasons for which we decided to work with this species for this study.

The biological stress was created through a preliminary experiment in the laboratory, using lipopolysaccharides (LPS), mimicking the impact of pathogenic contamination, and inducing an inflammatory reaction (Hang et al. 2013; Swain et al. 2008; Xiang et al. 2008). LPS were then injected in fish previously caged for 14 days in one high metal-contaminated pond, including uranium, or in two other ponds with lower metallic concentrations and without uranium. Four days after these injections, some biomarkers were analysed, including immunomarkers, markers often used for assess effects of a biological stress, and the antioxidant system, commonly used for metallic stress (Amiard and Amiard Triquet 2008).

\section{Materials and methods}

\subsection{Determination of a biological stress and effects of anesthesia and injections.}

In order to create a biological stress visible on selected biomarkers, a preliminary study in the laboratory was conducted. This experiment aimed to determine the Escherichia coli LPS (0127: B8, Sigma, St. Louis, MO, USA) concentration necessary to induce a biological stress and to determine the latency time between LPS injection and fish dissection to limit anesthesia and/or injection stress. The experimental design is schematized on the figure 1.

Prior to this experiment, 180 sticklebacks $(2.03 \pm 0.64 \mathrm{~g} ; 5.38 \pm 0.72 \mathrm{~cm})$ were acclimatised for two weeks in the laboratory ( 5 tanks with 35 litters of water; fish density: $2.32 \mathrm{~kg} / \mathrm{m}^{3}$; the third of the water volume is changed every two days.), with two tanks corresponded to control 
organisms, and the other three corresponded to fish submitted to the three different LPS concentrations (one tank per treatment; 3, 6 and $9 \mathrm{mg}$ of LPS per $\mathrm{kg}$ of fish). Sticklebacks were fed every day, before their manipulation (dissection of injection), with bloodworms (ratio of food/fish of $3 \%$ w/w, Ocean Nutrition Europe, Essen, Belgium).

In order to determine the biological stress, after acclimatisation step, sticklebacks were anesthetised by balneation, using tricaine methanesulfonate (MS222, $0.1 \mathrm{~g} / \mathrm{L}$, Molekula, Irvine, CA, USA), to undergo an injection of LPS or their solvent (phosphate buffer saline, PBS, Sigma) performed using Hamilton syringes (25 $\mu \mathrm{L}$, Hamilton, Reno, NV, USA). Volumes for intraperitoneal injections were adjusted according to fish weight and never overpassed $10 \mu \mathrm{L}$ per fish (ratio liquid/fish weight: $3.33 \mu \mathrm{L} / \mathrm{g}$ ). After sticklebacks were awakened in an aquarium intended for this purpose, they were returned to their respective aquarium. One, two, four and eight days after these injections, ten fish per condition (PBS and the three LPS concentrations) were sacrificed by cervical dislocation.

In order to limit anesthesia and injection potential stress, a first group of ten sticklebacks was not submitted to anesthesia or injection before being sacrificed by cervical dislocation, while fish from the second control group $(n=10)$ were only anesthetised, but not submitted to injection. For these groups, dissections and analyses were made only on D+1.

Total size and weight were recorded to calculate Fulton's K condition index (K), the spleen was recovered for immune capacity analyses, and the liver for antioxidant system and lipid peroxidation analyses. Detailed protocols of these analyses are described below (Part 2.3.). According to results (Annex 1), a concentration of $9 \mathrm{mg}$ of LPS $/ \mathrm{kg}$ of fish and 4 days of latency time $(\mathrm{D}+4)$ were chosen compared to the other treatment and sampling time conditions.

\subsection{Fish exposure to the chemical stress}

2.2.1. Localisation and physical and chemical parameters of selected ponds Three ponds were chosen according to their level of metal contamination and their proximity to uranium mining site in the Haute-Vienne department (France, Figure 2). One of these ponds received uranium tailings from former mines (the Pontabrier pond) and two other ponds without these tailings (the Malessard and Jonchère Saint-Maurice ponds) (Figure 2). 
Oxygen level, $\mathrm{pH}$ and conductivity were measured at the beginning of the experiment and on the injection day, while temperature was continuously (each hour) recorded with a probe inside cages (HOBO Pendant Temperature Data Logger, Onset, Bourne, MA, USA). Trace metal concentrations in water $\left(50 \mathrm{~mL}\right.$ of acidified water $\left(\mathrm{HNO}_{3}, 2 \%\right.$, VWR, Radnor, PA, USA), non-filtered and filtered with $0.45 \mu \mathrm{m}$ syringe filter, three replicates) were measured by inductively coupled plasma mass spectrometry (ICP-MS, Agilent Model 7500 Cs, Santa Clara, CA, USA; detection limit: $10 \mathrm{ng} / \mathrm{L}$ for all metals) and major cation concentrations by inductively coupled plasma-atomic emission spectrometry (ICP-AES Optima 4300DV, PerkinElmer, Wellesley, MA, USA). Major anions were measured in $50 \mathrm{~mL}$ of non-filtered acidified water $\left(\mathrm{HNO}_{3}, 2 \%\right)$ using an ionic chromatograph (Dionex DX-120, Sunnyvale, CA, USA). Total inorganic carbon (TIC) and total organic carbon (TOC) were assessed using a TOC analyser (Schimadzu 5000A, Schimadzu Scientific Instruments, Columbia, MD, USA).Water samples from Haute-Vienne ponds were collected to analyse the presence or absence of polychlorinated biphenyls (PCBs), polycyclic aromatic hydrocarbons (PAHs), volatile organic compounds (VOCs), cyanobacteria, as well as six major pesticides used in the region (glyphosate, AMPA, 2.4D, DCMU, atrazine and triclopyr) (GrapLimousin 2007). These analyses were carried out by the regional laboratory of water control (city of Limoges, France).

\subsubsection{Experimental design of the in situ experiment}

The figure 3 summarizes the protocol used. This experiment was conducted in March and April 2014 with 90 three-spined sticklebacks coming from INERIS husbandry. To limit individual variations, fish came from the same initial fish group, were one year old and were standardized in length and weight $(1.44 \pm 0.18 \mathrm{~g} ; 5.44 \pm 0.19 \mathrm{~cm})$. Before being caged, sticklebacks were acclimatised in the laboratory to the physical and chemical properties of ponds (temperature: $12{ }^{\circ} \mathrm{C}$; $\mathrm{pH}$ : 7; conductivity: $50 \mu \mathrm{S} / \mathrm{cm}$ ) for two weeks. On the field, fish were maintained in cylindrical cages (height: $460 \mathrm{~mm}$; radius: $125 \mathrm{~mm}$; volume: $22.58 \mathrm{~L}$ ). These cages were divided in two parts in order to reduce the fish number used for scientific purposes. Cages were placed directly on the sediment at a water depth of $500 \mathrm{~mm}$. The meshes of these cages $(3.5 \times 3.5 \mathrm{~mm})$ prevented fish from escaping and allowed the pass of some small organisms, such as worm, larvae or plankton, being part of the diet of sticklebacks (Allen and Wootton 1984; Hynes 1950). Sticklebacks received no supplementary food intake throughout the experiment. 
Before and during caging, females and males were distributed in cages in order to have a sex ratio close to 1 . No difference of results between females and males was observed during this experiment, except for GPx activity (data not shown). During the breeding season, as it has been already observed by (Sanchez et al. 2007; 2008b), female sticklebacks presented higher GPx activity than males $(89.21 \pm 30.52 \mathrm{U} / \mathrm{g}$ of total proteins for females against $20.69 \pm 11.23$ $\mathrm{U} / \mathrm{g}$ of total proteins for males; data not shown). This difference did not exist when the experiment took place outside the breeding period (data not shown). This high activity for females during the breeding period could be explained by an important hormonal metabolism (Burk et al. 1980; Sanchez et al. 2008b). Despite this difference between sexes, no effect on stickleback responses to the polymetallic contamination or to LPS was recorded (data not shown). For all of these reasons (few significant differences between males and females; no effect on responses to metal contamination or to LPS), we decided to group female and male results in this study.

At each pond, 30 sticklebacks were distributed in two half-cages, one cage for the LPS condition and the other for the PBS condition (Figure 3), with a density of $2.31 \mathrm{~kg} / \mathrm{m}^{3}$. This density was chosen between the OECD recommendations for rainbow trout (Onchorhynchus mykiss) and medaka (Oryzias latipes) densities (OECD 2000). Fourteen days after caging, sticklebacks were anesthetised by balneation with MS222 (0.1 g/L of water from ponds, Molekula) and submitted to E.coli LPS ( $9 \mathrm{mg}$ of LPS/kg of fish, Sigma) or PBS (Sigma) injections. Prior to be caged once again, fish were placed in a tank filled with water from each pond until their awakening. Four days after these injections, sticklebacks were sacrificed by cervical dislocation. Total size and weight, as well as liver weight were recorded to calculate biometric indices. Blood and spleen from each fish were removed and kept at $4{ }^{\circ} \mathrm{C}$ until DNA damage and immune capacity analyses, respectively. Finally, liver used for antioxidant system and lipid peroxidation assessment was frozen in liquid nitrogen with a buffer $(400 \mu \mathrm{L}$ of potassium phosphate buffer (100 mM, pH: 7.4, Sigma) modified with glycerol (20\%, Sigma) and phenylmethylsulfonyl fluoride (PMSF, $2 \mu \mathrm{M}$, Sigma) before being stored at -80 ${ }^{\circ} \mathrm{C}$.

\subsection{Biological parameters}

\subsubsection{Biometric indices}

Fulton's K condition index evaluates the general well-being of fish and is calculated by the formula: $K=\left(\right.$ weight/length $\left.{ }^{3}\right) \times 100$. The hepato-somatic index (HSI) is calculated by the formula: $\mathrm{HSI}=($ liver weight/total body weight $) \times 100$. 


\subsubsection{Immune capacities}

The splenic leucocyte isolation was performed following previous described method (BadoNilles et al. 2014b). In the same way, the leucocyte necrosis and apoptosis, the percentage of lymphocyte among leucocytes, the lysosomal membrane integrity (LMI), the respiratory burst, and the phagocytic capacity were made and analysed following protocols previously described (Bado-Nilles et al. 2013; Bado-Nilles et al. 2014a; Chilmonczyk and Monge 1999; Gagnaire et al. 2015; Gust et al. 2013).

Phagocytic capacity was calculated as: (cells ingesting at least 3 fluorescent microbeads/cells ingesting at least 1 fluorescent microbead) $\times 100$ (Gust et al. 2013). A visualisation of phagocytosis with transmission electron microscopy (TEM) was realised to confirm this phagocytosis. The protocol was the same as previously described with some modifications for TEM observations. In order to have a fairly large pellet, the samples were grouped by four. The diameters of the microbeads used were 1 and $2 \mu \mathrm{m}$, and these beads were removed from the sample after incubation, with gentle agitation, using a bovine serum albumin gradient (3 $\%, 1 \mathrm{~mL}$, Sigma). Centrifugation (100 g, $\left.10 \mathrm{~min}, 4{ }^{\circ} \mathrm{C}\right)$ was necessary to pellet leucocytes. These pellets were fixed using glutaraldehyde $(2.5 \%$ in $0.1 \mathrm{M}$ sodium cacodylate buffer, $\mathrm{pH}$ 7.4, Electron Microscopy Sciences, Hatfield, PA, USA) for 2 days at $4{ }^{\circ}$ C. Samples were washed three times and were then postosmicated for $1 \mathrm{~h}$ in osmium tetroxide $(1 \%$ in cacodylate buffer, Electron Microscopy Sciences). They were dehydrated through a graded ethanol series and finally embedded in monomeric resin Epon 812 (Electron Microscopy Sciences). Ultrathin sections (80 and $110 \mathrm{~nm}$ ) were obtained using an ultra-microtome (UCT, Leica Microsystems GmbH, Wetzlar, Germany). For ultrastructural analysis, ultrathin sections were mounted on copper grids and examined with a Tecnai G2 Biotwin Electron Microscope (100 kV, FEI Company, Eindhoven, the Netherlands) equipped with a CCD camera Megaview III (Olympus Soft imaging Solutions GmbH, Münster, Germany).

Respiratory burst is described by three parameters: ROS basal level, which corresponds to ROS production by unstimulated cells observed with the 2'-7'-dichlorofluorescin diacetate probe $\left(\mathrm{H}_{2} \mathrm{DCFDA}, 60 \mu \mathrm{M}\right.$, Sigma); ROS activated level, which corresponds to ROS production by stimulated cells by phorbol 12-myristate 13-acetate (PMA, $15 \mu \mathrm{M}$, Sigma) and the stimulation index of respiratory burst, which is calculated by the formula: fluorescence of ROS activated/fluorescence of ROS basal (Chilmonczyk and Monge 1999). Leucocyte activities were evaluated by flow cytometry with 10,000 events counted for each suspension 
sample. Data were recovered using a Guava®EasyCyteTM 8HT flow cytometer (Merck Millipore, Billerica, MA, USA) and analysed using Guavasoft 2.7 software.

\subsubsection{Oxidative stress}

Protein concentration was assessed using (Bradford 1976) method with bovine serum albumin (Sigma for both products). Among hepatic biomarkers, glutathione (GSH) (Vandeputte et al. 1994), glutathione-S-transferase (GST) (Habig et al. 1974), glutathione peroxidase (GPx) (Paglia and Valentine 1967), glutathione reductase (Gr) (Carlberg and Mannervik 1975), catalase (CAT) (Babo and Vasseur 1992), superoxide dismutase (SOD) (Paoletti et al. 1986), and thiobarbituric acid reactive substances (TBARS) for lipid peroxidation assessment (Ohkawa et al. 1979), were analysed. All these measurements were adapted on stickleback by (Sanchez et al. 2005) and (Sanchez et al. 2007). Except for TBARS and GSH (fluorescence units and $\mu \mathrm{mol} / \mathrm{g}$ of total protein, respectively), all results were calculated in $\mathrm{U} / \mathrm{g}$ of total protein.

\subsubsection{DNA damage}

DNA damage were assessed using comet assay described by (Santos et al. 2013), with minor modifications, described below. Blood samples were kept at $4{ }^{\circ} \mathrm{C}$ in $800 \mu \mathrm{L}$ of $\mathrm{L} 15$ medium Leibovitz (L15, Sigma) modified with heparin lithium (20 U/mL, Sigma), penicillin (500 $\mathrm{U} / \mathrm{mL}$, Sigma) and streptomycin $(500 \mu \mathrm{g} / \mathrm{mL}$, Sigma) until analysis (48 $\mathrm{h}$ after blood collection). Slides were transposed for $20 \mathrm{~min}$ instead of $40 \mathrm{~min}$ in an electrophoresis tank filled with electrophoresis buffer $(300 \mathrm{mM} \mathrm{NaOH}, 1 \mathrm{mM}$ EDTA, qsp 1.5L of osmotic water, Sigma for both products). Several genotoxicity parameters were recorded using Comet Assay 4 software. One hundred cells per slide (two slides per sample) were randomly selected for analysis.

\subsection{Statistical analyses}

$\mathrm{R}$ software (3.1.1 version) was used for all statistical analyses. The number of replicates depended to the nature of the physical and chemical studied ( $n=17$ for temperature; $n=3$ for metals concentration; $n=2$ for anions / cations; $n=1$ for conductivity and $\mathrm{pH}$ ). Differences of chemical and physical parameters between ponds were assessed using one-way ANOVA. Normality and homogeneity assumptions were assessed by the Shapiro-Wilk and Levene tests on residuals, respectively. If normality and homoscedasticity were respected, ANOVA was 
kept and was followed by a Tukey test, otherwise, ANOVA was replaced by a Kruskal-Wallis test followed by a Mann-Whitney test with Holm correction.

Concerning biomarkers, the number of replicates was 15 sticklebacks per injection condition and per pond. Normality and homogeneity assumptions were assessed applying respectively Shapiro Wilk and Levene tests on residuals. If at least one of these assumptions were not satisfied, a log transformation of the dependent variable was first applied and assumptions checked again. For some biomarkers the log transformation failed to reach homogeneity. In this case, a variance function was used to model the variance structure. The significance of the interaction between the variables "pond" and "injection" was assessed with the type-3 squares, and were followed, if these values were significant, by multiple comparisons (Tukey test) to observe the differences within the conditions. For all the analyses, significance level fixed at 5 $\%$. Principal component analyses (PCA) were performed with two components with all of stickleback responses, and through two dimensions.

\section{Results}

\subsection{Determination of LPS concentrations and the latency time between injection and dissection}

During the preliminary experiment performed in the laboratory, an effect of anesthesia and/or injection was observed on $\mathrm{D}+1$ and/or on $\mathrm{D}+2$ on several biomarkers (leucocyte necrosis, LMI, phagocytic capacity, ROS basal and activated levels, GSH, CAT, SOD and TBARS; Annex 1). These two sampling time were therefore not retained for the in situ experiment.

The concentration of $9 \mathrm{mg}$ of LPS per $\mathrm{kg}$ and a latency time of four days (D+4) were chosen because the most important effects were recorded for these conditions. Indeed, compared to other LPS concentrations, $9 \mathrm{mg} / \mathrm{kg}$ injections has resulted in significant higher ROS activated level, stimulation index of respiratory burst, and lower GSH contents, CAT and GST activities (Annex 1). A latency time of eight days was not selected because of some biomarker levels came back to a basal level, such as ROS activated level, stimulation index of respiratory burst and phagocytic capacity compared to D+2 (Annex 1).

Thus a concentration of $9 \mathrm{mg}$ of LPS/kg of fish and 4 days of latency time (D+4) were chosen and applied in the field.

\subsection{Physical and chemical properties of ponds}

Although a temperature slightly higher in the Jonchère Saint-Maurice pond compared to the other two ponds (Table 1), temperature kinetic inside ponds were the same (Annex 2). 
Concerning the other physical parameters, $\mathrm{pH}$ was higher in the Jonchère Saint-Maurice pond, while conductivity and dissolved oxygen level were higher in the Pontabrier pond (Table 1). As mentioned in a previous study (Le Guernic et al. submitted), only metals mainly present in the water-dissolved fraction (> $10 \mu \mathrm{g} / \mathrm{L}$, except for uranium) and exceeding their predicted no-effect concentrations (PNEC) and or their no-observed effect concentrations (NOEC) were listed in the Table 1. Other metals $(\mathrm{Cd}, \mathrm{Cu}, \mathrm{Co}, \mathrm{Zn}, \mathrm{Pb}$ and $\mathrm{Ni}$ ) were therefore not indicated in this study. The Pontabrier pond, which receives mine tailings, presented the higher metallic concentrations than the other two ponds, and three of these differences were significant (Table 1). This contaminated pond presented at least twice the concentration of aluminum and manganese, and 200 times more uranium than reference ponds (Table 1). Except for iron, the Jonchère Saint-Maurice presented the lowest metallic concentrations among the three ponds (Table 1). The Pontabrier pond also presented higher concentrations of calcium, sodium, chloride, sulphate, and inorganic carbon, while all of these anions and cations were found at lower concentrations in the Malessard pond than in the other two ponds (Table 1). No other contamination source was found in the three ponds (levels of PAHs, PCBs, VOCs, pesticides and cyanobacteria were under the detection limit).

\subsection{Individual mortality}

No sticklebacks died during this experiment. Moreover, no sign of stress (skin coloration, injuries, parasites), as well as no behavioural alteration, were observed after injection or after caging (abnormal reaction when out of water, no swimming).

\subsection{Biological effects of the chemical stress, the biological stress and both combined}

\subsubsection{Effects due to the chemical stress (polymetallic contamination)}

For this section, only results from sticklebacks caged in the three different ponds and submitted to PBS injections are presented. Fish caged in the Pontabrier pond presented a lower condition index than fish caged in the other two ponds, and significantly with the Malessard pond ( 0.83 compared to 0.97 ; Table 2 ). K was the only biometric index impacted by caging ponds.

Few components of the immune system were impacted by the polymetallic contamination. Indeed, leucocyte apoptosis, lymphocyte percentage and phagocytic capacity were similar for fish caged in the three ponds. Nevertheless, fish caged in the highest metal-contaminated pond presented the lower leucocyte necrosis $(4.86 \%$ for the Pontabrier pond significantly different to $7.98 \%$ for the Jonchère Saint-Maurice pond; Table 2). LMI varied greatly according to 
ponds. This biomarker was significant higher in the Malessard pond (238 fluorescence units, FU), while it was lower in the Jonchère Saint-Maurice pond (152 FU) (Table 2).

The polymetallic contamination induced a significant increase of basal ROS production in fish caged in the Pontabrier pond (Table 2). As ROS activated level did not differ between ponds, the stimulation index (SI) of respiratory burst was twice and significant reduced by exposure to the Pontabrier pond compared to the reference ponds (Table 2).

Concerning the antioxidant system, some activities were significantly stimulated in the most metal-contaminated pond than in the reference ponds, such as SOD and GST (Table 2). Gr was significantly higher in the Malessard pond than in the Jonchère Saint-Maurice pond while GSH amount were significantly lower in this pond (Table 2). Finally, GPx and CAT were not impacted by exposure to the different ponds when sticklebacks were submitted to a PBS injection (Table 2).

Lipid peroxidation was twice higher in fish liver from the uranium-contaminated pond compared to the other ponds (from about 10,000 FU to about 20,000 FU; Table 2). Interestingly, DNA damage were significantly higher in the lowest metal-contaminated pond compared to in the highest metal-contaminated pond (Table 2).

\subsubsection{Effects due to the biological stress (LPS injection)}

Only three effects due to LPS observed in the laboratory were also reported on the field, depending on the pond (Table 2 and Table 3). In fact, almost all effects were also observed, but were only trends, and were not significant. These similarities are reported in the table 4 . In addition to these similarities, leucocyte necrosis and apoptosis tended to increase in each pond after LPS injection compared to PBS injection, with a significant increase of apoptosis in the Jonchère-Saint-Maurice pond (Table 2). These effects were also noted during the preliminary experiment, but eight days after LPS injections (Annex 1). Nonetheless, the leucocyte apoptosis, as well as the phagocytic capacity were significantly higher after LPS injection compared to the solvent injection for fish caged in the Jonchère Saint-Maurice (Table 2). Concerning antioxidant system, only a significant decrease of GST activity due to LPS injection was reported for fish caged in the contaminated pond (Table 2).

\subsubsection{Impacts of the chemical stress on fish responses to the biological stress}

PCA were performed using two dimensions, representing $35 \%$ of the total inertia. Axis 1 is mainly explained (> $10 \%$ ) by five biomarkers (leucocyte necrosis, respiratory burst stimulation index, GSH, GST and TBARS) while axis 2 is mainly explained by four 
biomarkers (leucocyte apoptosis, LMI, ROS activated and Gr) (Figure 4). The circles of ponds (explicative variable) did not overlap (Figure 4A), whereas those of injection conditions overlapped (Figure 4B). However, ponds, like the injection conditions, were not distributed according to axes (PC1 or PC2), hence the need to assess the interactions between stress on biomarkers measured.

Exposure to the polymetallic contamination impacted some responses to LPS injection. These significant interactions between pond and injection of LPS were scored in the table 3 . Phagocytic capacity and TBARS were impacted by both stress $\left(p=2.33 \times 10^{-2}\right.$ and $p=2.89 \times$ $10^{-8}$, respectively), as well as for GSH and CAT if we considered a higher $p$-value ( $p=5.44 \times$ $10^{-2}$ and $p=7.20 \times 10^{-2}$, respectively) (Table 3 ).

Lipid peroxidation tended to decrease in liver from fish caged in the uranium-contaminated pond after LPS injections (from 20,000 to 12,700 FU), while not in the other two ponds (Tables 2 and 3). In addition to this difference, some other differences were observed in the lowest metal-contaminated pond (the Jonchère Saint-Maurice pond). The phagocytic capacity was significantly enhanced by LPS injection when fish were caged in this pond (from 7.9 to $9.4 \%$; Table 2). A less pronounced difference (not significant) was the decrease of GSH levels after LPS injections in the Pontabrier and the Malessard ponds, but not in the lowest contaminated pond (a loss of about $3 \mathrm{U} / \mathrm{g}$ of total protein; Table 2). The catalase activity decreased after LPS injections in the Jonchère Saint-Maurice pond (- 209,000 U/g of total protein; Table 2), whereas an increase in the Pontabrier pond was reported $(+137,000 \mathrm{U} / \mathrm{g}$ of total protein; Table 2).

\section{Discussion}

\subsection{Polymetallic contamination linked to former uranium mines}

As previously described, the Pontabrier pond presented the highest metallic concentrations, especially for uranium, due to tailings from several former uranium mines, result corroborated by some studies (Gagnaire et al. 2015; Herlory et al. 2013; Marques et al. 2013; Pereira et al. 2008). This higher metallic contamination was accompanied by calcium and sulphate contents, more important in this pond. Iron concentrations were important for the three studied ponds $(\geq 0.2 \mathrm{mg} / \mathrm{L}$ ), and generally found at high concentrations closed to former uranium mining site in this department. This metal, with the manganese, constitute the chemical signature of water in these abandoned mines (GEP 2010).

Compared to the metallic concentrations in the same ponds and the same period but the previous year (Le Guernic et al. submitted), the metallic contamination found in the 
Pontabrier pond did not differ, except for a slight increase of uranium concentration for the second year. Nonetheless, compared to the first year (April 2013), metal concentrations measured in the Malessard pond in the present study were higher, while iron and aluminum concentrations in the Jonchère Saint-Maurice decreased, inducing that the lower metal concentrations were found in this study for the Jonchère Saint-Maurice pond.

Concerning potential confounding factors, daily variations of temperature (Annex 2) were identical between the ponds. Nonetheless, the Jonchère Saint-Maurice pond had warmer water than the other two ponds $\left(+1.50{ }^{\circ} \mathrm{C}\right.$ compared to the Malessard pond and $+2{ }^{\circ} \mathrm{C}$ compared to the Pontabrier pond). No study have assessed the effect of a temperature difference of $2{ }^{\circ} \mathrm{C}$, and the lowest temperature difference having led to an effect on the fish (rainbow trout, Oncorhynchus mykiss and Mozambique tilapia, Oreochromis mossambicus) was + or $-4{ }^{\circ} \mathrm{C}$ (Hardie et al. 1994; Ndong et al. 2007). Regarding conductivity levels, this parameter was quite low (from 8 to $18 \mu \mathrm{S} / \mathrm{cm}$ ). These values were nevertheless common in this department as reported by (Gagnaire et al. 2015) and (Le Guernic et al. submitted). Finally, dissolved oxygen levels were high (from 11.79 to $13.14 \mathrm{mg} / \mathrm{L}$ ), resulting in a hyperoxic context (Caldwell and Hinshaw 1994; Cuenco et al. 1985). Recorded temperature and pH, closed to neutrality, were in the range of stickleback's well-being (Sanchez et al. 2007; Wootton 1984). Moreover, the small difference of these four parameters between ponds, lack of data on small temperature differences and the acclimatisation step before caging allowed to consider these environmental parameters as negligible and not affecting the biological responses of the stickleback.

\subsection{Polymetallic contamination effects on stickleback health (without LPS)}

The polymetallic contamination found in the Pontabrier pond seemed to have an effect on fish condition. Indeed, Fulton condition index was lower in this pond compared to the other two ponds. Other studies have shown this same effect on condition index due to metals (Kerambrun et al. 2012; Laroche et al. 2002; Roussel et al. 2007). Two weeks of metallic exposure appeared to be a short period to decrease the condition index of an adult fish. This lower $\mathrm{K}$ in the Pontabrier pond could be due to a potential difference of food intake by fish between ponds. (Pottinger et al. 2002) have reported a decrease of stickleback condition index after two weeks of complete starvation. HSI was not impacted by the polymetallic contamination for 14 days. This result was corroborated with other studies (Maceda-Veiga et al. 2013; Roussel et al. 2007). 
Metals are known to induce oxidative stress on fish (Andersen et al. 1998; Fernandez-Davila et al. 2012; Lushchak 2011; Qu et al. 2014; Sanchez et al. 2007). In our study, polymetallic exposure for 14 days also induced oxidative stress on sticklebacks. Indeed, this stress was visible by the increase of ROS basal level by splenic leucocytes. This increase in ROS basal level after metal exposure has already been observed in several studies (Farina et al. 2013; Gagnaire et al. 2014; Jolly et al. 2014; Sevcikova et al. 2011). Nonetheless, some studies highlighted a decrease of ROS basal level after metallic exposure (Gagnaire et al. 2015; Sanchez-Dardon et al. 1999). (Sanchez-Dardon et al. 1999) have also observed higher decrease of respiratory burst of rainbow trout after exposure to a combination of metals. The leucocytes contained in the spleen of fish maintained in the Pontabrier pond produced a higher ROS basal level than fish caged in the other two ponds, but the polymetallic contamination did not induce an overproduction of ROS after PMA-stimulation. Thus, the respiratory burst stimulation index was lower in the Pontabrier pond. As previously described by (Gagnaire et al. 2014), it is possible that the ROS production initial level at the Pontabrier pond was too high to be further stimulated by the PMA. Thus, exposure to the highest metallic concentrations induced pro-oxidant effects on three-spined sticklebacks.

The activation of the antioxidant system was shown in the uranium-contaminated pond, with higher activities of GST and CAT in fish caged in the Pontabrier pond, compared to the other two ponds.

This overproduction of basal ROS can lead to oxidative damage, such as the alteration of biological membranes, by destabilizing the lipid bilayer. This effect was observed in liver from sticklebacks caged in the Pontabrier pond, with a higher lipid peroxidation than in the other two ponds. In these reference ponds, the lipid peroxidation level was equal to that previously assessed in the laboratory, without metallic exposure (from 9,240 to 15,463 FU; Annex 1). Several studies also reported this lipid peroxidation due to metals (Ferreira et al. 2008; Pandey et al. 2008; Ruas et al. 2008; Vieira et al. 2012). A negative correlation between LMI and TBARS should be expected, especially as some studies have shown highlighted a destabilization of lysosomal membrane after metal contamination (Moore et al. 2004; Regoli et al. 1998). However, LMI was not modified by the polymetallic contamination. This biomarker was low in the lowest contaminated pond, describing a destabilization of the biological membrane, and could be linked to the higher leucocyte necrosis for sticklebacks caged in this pond, normally impaired by a metallic exposure (Dunier 1996; Garcia-Medina et 
al. 2011). Nevertheless, (Gagnaire et al. 2015) showed higher leucocyte mortality in roach, Rutilus rutilus, in a non-uranium contaminated pond.

Another known oxidative damage can be measured at the DNA levels (Barillet et al. 2005; Garcia-Medina et al. 2011; Yadav and Trivedi 2009). Nonetheless, in our study, sticklebacks caged in the lowest metal-contaminated pond presented the higher level of DNA damage. Metals are not the main factor to induce genotoxicity in fish (Wirzinger et al. 2007). Other factors can lead to DNA damage, such as temperature (Bony et al. 2008; Mitchelmore and Chipman 1998), or pH (De Andrade et al. 2004).

This low LMI and high DNA damage and leucocyte necrosis indicated that fish caged in the Jonchère Saint-Maurice pond may have been submitted to another stress than metals, not assessed in our study, such as environmental factors or food availability.

Some biomarkers did not vary among metallic contamination, such as phagocytic capacity and some antioxidant enzymes (CAT, GPx). It is important to note that the phagocytic percentage found in each pond (from 7.43 to $7.97 \%$ ) was lower than the basal level measured in the laboratory (from 8.67 to $16.20 \%$ ), or even in another in situ experiment (from 8.47 to $9.06 \%$; (Le Guernic et al. submitted)). Although this phagocytic capacity, assessed by flow cytometry, was low compared to with that of the literature, we affirmed these phagocytic phenomena by TEM analyses. Indeed, the microscopic visualizations of the microbeads ingested by leucocytes confirmed that we have evaluated phagocytosis, not adhesion to the immune cell (Annex 3).

In conclusion, fish exposed to the highest polymetallic contamination found in the Pontabrier pond were submitted to an oxidative stress, through the increase of ROS production, causing increases of GST and CAT activities and inducing a lipid peroxidation.

\subsection{LPS effects on stickleback health}

In the laboratory, the most important effects due to LPS were observed for immune capacities (increases of phagocytic capacity and ROS production). This is in accordance with the LPS nature. Indeed, they are known to impact the immune system of fish, by inducing an inflammatory response (Swain et al. 2008). They have many immunostimulating effects, such as the leucocytosis, increase of ROS production, phagocytosis, activating macrophage and complement system, and can also alter the antioxidant systems or the lipid and carbohydrate metabolisms (Hang et al. 2013; Jolly et al. 2014; Swain et al. 2008; WaagbØ 1994; Xiang et al. 2008). Nevertheless, almost all significant effects observed in the laboratory became trends 
in the field (Table 4). A hypothesis to explain these differences between laboratory and in situ results can be linked to the difference of exposure conditions. In the laboratory, physical and chemical conditions were fixed and controlled compared to the in situ experiment, however fish caged in ponds were exposed to metals. The effects of LPS may be mitigated by exposure to metals in each pond.

\subsection{Polymetallic contamination effects on stickleback responses to LPS injection}

The literature on effects of metals on fish susceptibility to a pathogen shows two important results:

The most recurring result is an increase of susceptibility against a biological stress. Indeed, it is well known that metals can alter defense system of fish, via destabilization of immune system, antioxidant system, etc. (Qu et al. 2014; Sanchez-Dardon et al. 1999; Sanchez et al. 2007), and these defenses are essentials for the protection against pathogens and diseases (Dunier 1996; Stolen and Fletcher 1994). Thus, immunosuppressive effects of metals can lead to a decrease of fish resistance to pathogens. (Knittel 1981) hypothesized that copper caused a decreased of leucocyte number in the steelhead trout (Salmo gairdneri), required for the immune defense against the Yersinia ruckeri infection. Prior exposure to metals can also reduce the phagocytosis activity, the ROS production, deteriorate immune cells or even alter the organic tissues (El-Boshy and Taha 2011; Sheir and Handy 2010; Stolen and Fletcher 1994). All these effects can then lead to increased susceptibility to pathogens. Metals can impair the acquired immunity by reducing the number of produced antibodies. This was the case for the cat fish (Heteropneustis fossilis) after cadmium and Aeromonas hydrophila exposures (Saxena et al. 1992). These effects were also observed with a metallic combination: a copper and methylmercury exposure induced alterations of the immune system of the blue gourami (Trichopodus trichopterus) (Roales and Perlmutter 1977). Susceptibility to pathogen does not vary only due to variations of immune system, and metals can also impact the physical condition of fish (Esteve et al. 2012).

- $\quad$ The second effect of a prior exposure to metals on pathogenicity, often observed in the literature, is that metals can create an immunostimulation, and thereby increase resistance against pathogens (Anderson 1996). This result has been observed by several studies. (Cossarini-Dunier 1987) showed an increase of macrophage phagocytosis of Yersinia ruckeri after manganese exposure of the carp. (Rougier et al. 1996) highlighted the fact that zinc can decrease the number of viruses found in the zebrafish (Brachidanio rerio). Even five metals 
(As, $\mathrm{Cu}, \mathrm{Cd}, \mathrm{Pb}$ et $\mathrm{Se}$ ) can improve protection of striped bass (Morone savatilis) against Flexibacter columnaris (MacFarlane et al. 1986). This improvement of protection against pathogen can be very high, as reported by (Ling et al. 1993) on the goldfish, where exposure to copper enhanced 15 times the resistance to Ichthyophthirius multifiliis.

(Anderson 1992) listed some metals that could create an immunostimulation in fish, but concluded that these border between immunosuppressive and immunostimulatory effects of metals are often difficult to assess. Depending on the concentration of cadmium, metal can be beneficial or harmful to the creation of antibodies against Bacillus cereus in the striped bass (Robohm 1986).

In our study, two-way analysis showed some effects of the interaction of contamination and injection on fish biomarkers. The lipid peroxidation and the phagocytic capacity were impacted by both stress, as well as for CAT and GSH if the statistical significance level increased from 0.05 to 0.1 .

The preliminary experiment allowed to show that LPS has stimulated immune responses, via increases of ROS activated level and phagocytic capacity. However, in the in situ experiment, only sticklebacks caged in the pond with the lowest metallic concentrations (the Jonchère Saint-Maurice pond) presented this phagocytic reaction to LPS. This result suggested that the caged fish in the least contaminated pond could be better able to activate their phagocytic capacity to respond to the LPS injection, contrary to fish caged in the other two ponds.

In addition to the phagocytic capacity, sticklebacks caged in this low contaminated pond maintained their GSH content after LPS injection, which was not the case of sticklebacks caged in the other two ponds. Although GSH contents were lower in the Jonchère SaintMaurice pond than in the other two ponds, values observed in the laboratory covered all values collected in the field (from 4 to $30 \mu \mathrm{mol} / \mathrm{g}$ of total proteins, in the laboratory). GST activity, which varied among ponds and injection conditions but not among their interaction, significantly decreased for fish caged in the Pontabrier pond after LPS injection. Glutathione being an essential substrate to the GST activity, its decrease has resulted in to a decline in activity of this enzyme. Studies focusing on the acclimation capacity of the antioxidant system with exposure to metals and pathogen are rare. However, it was observed a protective effect of parasite (Ptychobothrium sp.) on the decrease of antioxidant system of the carp (Cyprinus carpio) caused by a copper exposure (Dautremepuits et al. 2002). 
A prior exposure to stronger metal concentrations seemed therefore increase susceptibility sticklebacks to a biological stress, preventing their phagocytic response and destabilizing their GSH level and GST activity.

Differences of LPS susceptibility were thus observed between the Pontabrier-Malessard ponds and the Jonchère Saint-Maurice pond. We can therefore hypothesise that these differences cannot be explained by the uranium concentration in the different ponds, but more by lower aluminum and manganese concentrations in the Jonchère Saint-Maurice pond compared to the other two ponds. Unfortunately, studies working on modifications of acclimation capacities to a biological stress by metals were not focused on these two metals. Several studies have reported increases of lipid peroxidation after LPS injection (Jolly et al. 2014; Sewerynek et al. 1995; Sugino et al. 1987). Despite of (Requintina and Oxenkrug 2003) have observed decreases of lipid peroxidation after LPS injections at low concentrations in mammals, the downward trend of TBARS after LPS injection observed in fish caged in the Pontabrier pond was probably not due to these injections. Simultaneously with this tendency to decrease of TBARS was observed a not significant increase of CAT activity. CAT can limit lipid peroxidation protecting the lipids of hydrogen peroxide. This role is shared with another enzyme, the glutathione peroxidase. (Béguel 2012) has reported that CAT is preferably chosen than GPx during large quantities of $\mathrm{H}_{2} \mathrm{O}_{2}$, and can be implemented when GSH contents decrease (Kumar and Rajagopal 2003).

It should be noted that few biomarkers reacted to both stress, and the exposure to the different ponds had more effects on stickleback biomarkers than injection conditions. This result can be observed by the difference of number of biomarker impacted by the pond variable (13) and those impacted by injection variable (3), after the two-way ANOVA (Table 2). This result was confirmed by PCA, where individuals were more distributed among ponds than among injection conditions (Figure 4). Nonetheless, except for modifications of TBARS, which were more due to the CAT activity than to interaction between ponds and LPS injections, sticklebacks previously exposed to a chemical stress presented a lower resistance to the biological stress.

\section{Conclusion}

The aim of this study was to determine if a preliminary exposure to a polymetallic contamination could modify fish responses to a sudden biological stress. Both of these stress had effects on fish, such as oxidative stress after the metal exposure and leucocyte apoptosis 
and phagocytosis after lipopolysaccharides injections. Sticklebacks previously caged in the two most metal-contaminated ponds had increased susceptibility to the biological stress exerted by lipopolysaccharides injections. This decrease of LPS resistance by metal exposure was defined by an inability of sticklebacks to activate their phagocytic response and to maintain their GSH level and GST activity after a sudden biological stress. This study showed the importance of immunomarkers within a multi-biomarkers approach to assess multipollution effects on three-spined sticklebacks.

As sometimes reported (Dick and Dixon 1985; Gill et al. 1992; Hetrick et al. 1979; Knittel 1981), fish can become acclimated to the presence of metals during a longer exposure. This acclimation can therefore change the effects of metals on the fish susceptibility to a biological stress. It would be interesting to increase the period of exposure to the polymetallic contamination found in the Haute-Vienne ponds preceding the biological stress (for example two months instead of two weeks) to reassess effects of this exposure on susceptibility to lipopolysaccharides.

\section{Acknowledgements}

The authors are deeply grateful to the owners of the different ponds for having allowed this experiment. This work was partly supported by IRSN, the financial support of the 181 DRC 46 program of the French Ministry for Ecology and Sustainable Development, and the ECCOREV research federation.

\section{Ethical statement}

These experiments were conducted in accordance with the European Commission's recommendation 2007/526/EC on revised guidelines for the accommodation and care of animals used for experimental and other scientific purposes. The registration number for ethics of INERIS laboratory is the B60-769-02. For sampling, to avoid bias in the immune responses, no anaesthetic overdose can be used for euthanasia of sticklebacks. Indeed, in the 2010/63 / EU Directive of the European Parliament and the 22 September 2010 Council about the protection of animals used for scientific purposes, this option is envisaged "if anesthesia is incompatible with the purpose of the procedure". Therefore, sticklebacks were rapidly sacrificed by cervical dislocation followed by destruction of the brain. This method has been approved by the Committee No. 96-CREMEAP (Regional Ethics Committee in Animal Experimentation of Picardy). 


\section{References}

Allen J, Wootton R (1982) The effect of ration and temperature on the growth of the threespined stickleback, Gasterosteus aculeatus L Journal of Fish Biology 20:409-422

Allen JRM, Wootton RJ (1984) Temporal patterns in diet and rate of food consumption of the three-spined stickleback (Gasterosteus aculeatus L.) in Llyn Frongoch, an upland Welsh lake Freshwater Biology 14:335-346 doi:10.1111/j.1365-2427.1984.tb00158.x

Almroth BC, Sturve J, Stephensen E, Holth TF, Förlin L (2008) Protein carbonyls and antioxidant defenses in corkwing wrasse (Symphodus melops) from a heavy metal polluted and a PAH polluted site Marine environmental research 66:271-277 doi:http://dx.doi.org/10.1016/j.marenvres.2008.04.002

Amiard J-C, Amiard Triquet C (2008) Les biomarqueurs dans l'évaluation de l'état écologique des milieux aquatiques. Lavoisier,

Andersen F, Lygren B, Maage A, Waagbø R (1998) Interaction between two dietary levels of iron and two forms of ascorbic acid and the effect on growth, antioxidant status and some non-specific immune parameters in Atlantic salmon $(<\mathrm{i}>$ Salmo salar $</ \mathrm{i}>$ ) smolts Aquaculture 161:437-451

Anderson DP (1992) Immunostimulants, adjuvants, and vaccine carriers in fish: applications to aquaculture Annual Review of Fish Diseases 2:281-307

Anderson DP (1996) Environmental factors in fish health: immunological aspects The fish immune system: organism, pathogen, and environment:289-310

Babo S, Vasseur P (1992) In vitro effects of Thiram on liver antioxidant enzyme activities of rainbow trout (Oncorhynchus mykiss) Aquatic toxicology 22:61-68

Bado-Nilles A, Betoulle S, Geffard A, Porcher JM, Gagnaire B, Sanchez W (2013) Flow cytometry detection of lysosomal presence and lysosomal membrane integrity in the three-spined stickleback (Gasterosteus aculeatus L.) immune cells: applications in environmental aquatic immunotoxicology Environmental science and pollution research international 20:2692-2704 doi:10.1007/s11356-012-1410-2

Bado-Nilles A, Jolly S, Porcher JM, Palluel O, Geffard A, Gagnaire B, Betoulle S, Sanchez W (2014a) Applications in environmental risk assessment of leucocyte apoptosis, necrosis and respiratory burst analysis on the European bullhead, Cottus sp Environ Pollut 184:9-17 doi:10.1016/j.envpol.2013.07.049

Bado-Nilles A, Techer R, Porcher JM, Geffard A, Gagnaire B, Betoulle S, Sanchez W (2014b) Detection of immunotoxic effects of estrogenic and androgenic endocrine disrupting compounds using splenic immune cells of the female three-spined stickleback, Gasterosteus aculeatus (L.) Environmental toxicology and pharmacology 38:672-683 doi:http://dx.doi.org/10.1016/j.etap.2014.08.002

Barillet S, Buet A, Adam C, Devaux A, Devaux A (2005) Does uranium exposure induce genotoxicity in the teleostean Danio rerio? First experimental results Radioprotection 40:S175-S181

Béguel JP (2012) Etude de la capacité antioxydante en lien avec la reproduction chez l'huître creuse Crassostrea gigas. Université de Bretagne occidentale

Bols NC, Brubacher JL, Ganassin RC, Lee LE (2001) Ecotoxicology and innate immunity in fish Developmental \& Comparative Immunology 25:853-873

Bony S, Gillet C, Bouchez A, Margoum C, Devaux A (2008) Genotoxic pressure of vineyard pesticides in fish: field and mesocosm surveys Aquatic toxicology 89:197-203

Bradford MM (1976) A rapid and sensitive method for the quantitation of microgram quantities of protein utilizing the principle of protein-dye binding Analytical biochemistry 72:248-254

Brousseau P, Dunier M, Deschaux P, De Guise S, Krzystyniak K, Fournier M (1997) Marqueurs immunologiques L Lagadic et al:287-315 
Burk RF, Lawrence RA, Correia MA (1980) Sex differences in biochemical manifestations of selenium deficiency in rat liver with special reference to heme metabolism Biochemical pharmacology 29:39-42

Caldwell CA, Hinshaw J (1994) Physiological and haematological responses in rainbow trout subjected to supplemental dissolved oxygen in fish culture Aquaculture 126:183-193 doi:http://dx.doi.org/10.1016/0044-8486(94)90259-3

Carlberg I, Mannervik B (1975) Purification and characterization of the flavoenzyme glutathione reductase from rat liver Journal of Biological Chemistry 250:5475-5480

Chilmonczyk S, Monge D (1999) Flow cytometry as a tool for assessment of the fish cellular immune response to pathogens Fish \& shellfish immunology 9:319-333

Chou H-Y, Peng T-Y, Chang S-J, Hsu Y-L, Wu J-L (1999) Effect of heavy metal stressors and salinity shock on the susceptibility of grouper (Epinephelus sp.) to infectious pancreatic necrosis virus Virus Research 63:121-129

Cossarini-Dunier M (1987) Effects of the pesticides atrazine and lindane and of manganese ions on cellular immunity of carp, Cyprinus carpio Journal of Fish Biology 31:67-73 doi:10.1111/j.1095-8649.1987.tb05295.x

Cuenco ML, Stickney RR, Grant WE (1985) Fish bioenergetics and growth in aquaculture ponds: II. Effects of interactions among, size, temperature, dissolved oxygen, unionized ammonia and food on growth of individual fish Ecological Modelling 27:191-206 doi:http://dx.doi.org/10.1016/0304-3800(85)90002-X

Dautremepuits C, Betoulle S, Vernet G (2002) Antioxidant response modulated by copper in healthy or parasitized carp (Cyprinus carpio L.) by Ptychobothrium sp. (Cestoda) Biochimica et Biophysica Acta (BBA) - General Subjects 1573:4-8 doi:http://dx.doi.org/10.1016/S0304-4165(02)00328-8

De Andrade VM, da Silva J, da Silva FR, Heuser VD, Dias JF, Yoneama ML, de Freitas TRO (2004) Fish as bioindicators to assess the effects of pollution in two southern Brazilian rivers using the Comet assay and micronucleus test Environmental and Molecular Mutagenesis 44:459-468 doi:10.1002/em.20070

Dick PT, Dixon DG (1985) Changes in circulating blood cell levels of rainbow trout, Salmo gairdneri Richardson, following acute and chronic exposure to copper Journal of Fish Biology 26:475-481

Dunier M (1996) Water pollution and immunosuppression of freshwater fish Italian Journal of Zoology 63:303-309

El-Boshy M, Taha R (2011) Effects of mercuric chloride on the immunological, hematological, biochemical parameters and diseases resistance of Nile Tilapia challenged with Aeromnas hydrophila Nat Sci 9:7-15

Esteve C, Alcaide E, Ureña R (2012) The effect of metals on condition and pathologies of European eel (Anguilla anguilla): In situ and laboratory experiments Aquatic toxicology 109:176-184 doi:http://dx.doi.org/10.1016/j.aquatox.2011.10.002

Eyckmans M, Celis N, Horemans N, Blust R, De Boeck G (2011) Exposure to waterborne copper reveals differences in oxidative stress response in three freshwater fish species Aquat Toxicol 103:112-120 doi:10.1016/j.aquatox.2011.02.010

Farina M, Avila DS, da Rocha JBT, Aschner M (2013) Metals, oxidative stress and neurodegeneration: a focus on iron, manganese and mercury Neurochemistry international 62:575-594

Fernandez-Davila ML, Razo-Estrada AC, Garcia-Medina S, Gomez-Olivan LM, Pinon-Lopez MJ, Ibarra RG, Galar-Martinez M (2012) Aluminum-induced oxidative stress and neurotoxicity in grass carp (Cyprinidae-Ctenopharingodon idella) Ecotoxicology and environmental safety 76:87-92 doi:10.1016/j.ecoenv.2011.09.012 
Ferreira M, Caetano M, Costa J, Pousao-Ferreira P, Vale C, Reis-Henriques MA (2008) Metal accumulation and oxidative stress responses in, cultured and wild, white seabream from Northwest Atlantic The Science of the total environment 407:638-646 doi:10.1016/j.scitotenv.2008.07.058

Förstner U, Wittmann GTW (2012) Metal pollution in the aquatic environment. Springer Science \& Business Media,

Gagnaire B, Bado-Nilles A, Betoulle S, Amara R, Camilleri V, Cavalié I, Chadili E, Delahaut L, Kerambrun E, Orjollet D, Palluel O, Sanchez W (2015) Former uranium mineinduced effects in caged roach: a multiparametric approach for the evaluation of in situ metal toxicity Ecotoxicology 24:215-231 doi:10.1007/s10646-014-1374-8

Gagnaire B, Bado-Nilles A, Sanchez W (2014) Depleted uranium disturbs Immune parameters in zebrafish, Danio rerio: an ex vivo/in vivo experiment Archives of Environmental Contamination and Toxicology 67:426-435 doi:10.1007/s00244-0140022-x

Garcia-Medina S, Razo-Estrada C, Galar-Martinez M, Cortez-Barberena E, Gomez-Olivan LM, Alvarez-Gonzalez I, Madrigal-Bujaidar E (2011) Genotoxic and cytotoxic effects induced by aluminum in the lymphocytes of the common carp (Cyprinus carpio) Comparative biochemistry and physiology Toxicology \& pharmacology : CBP 153:113-118 doi:10.1016/j.cbpc.2010.09.005

GEP (2010) Recommandations pour la gestion des anciens sites miniers d'uranium en France. Des sites du Limousin aux autres sites du court aux moyen et long termes.

Gill TS, Bianchi CP, Epple A (1992) Trace metal ( $\mathrm{Cu}$ and $\mathrm{Zn}$ ) adaptation of organ systems of the American eel, Anguilla rostrata, to external concentrations of cadmium Comparative Biochemistry and Physiology Part C: Comparative Pharmacology 102:361-371

GrapLimousin (2007) Mesures des pesticides en Limousin. Bilan du suivi 2007.

Gust M, Fortier M, Garric J, Fournier M, Gagne F (2013) Immunotoxicity of surface waters contaminated by municipal effluents to the snail Lymnaea stagnalis Aquat Toxicol 126:393-403 doi:10.1016/j.aquatox.2012.09.001

Habig WH, Pabst MJ, Jakoby WB (1974) Glutathione S-transferases the first enzymatic step in mercapturic acid formation Journal of Biological Chemistry 249:7130-7139

Hang BT, Milla S, Gillardin V, Phuong NT, Kestemont P (2013) In vivo effects of Escherichia coli lipopolysaccharide on regulation of immune response and protein expression in striped catfish (Pangasianodon hypophthalmus) Fish \& shellfish immunology 34:339-347 doi:10.1016/j.fsi.2012.11.025

Hardie LJ, Fletcher TC, Secombes CJ (1994) Effect of temperature on macrophage activation and the production of macrophage activating factor by rainbow trout (Oncorhynchus mykiss) leucocytes Developmental \& Comparative Immunology 18:57-66

Heier LS, Teien HC, Oughton D, Tollefsen KE, Olsvik PA, Rosseland BO, Lind OC, Farmen E, Skipperud L, Salbu B (2013) Sublethal effects in Atlantic salmon (Salmo salar) exposed to mixtures of copper, aluminium and gamma radiation Journal of environmental radioactivity 121:33-42 doi:10.1016/j.jenvrad.2012.04.004

Herlory O, Bonzom JM, Gilbin R, Frelon S, Fayolle S, Delmas F, Coste M (2013) Use of diatom assemblages as biomonitor of the impact of treated uranium mining effluent discharge on a stream: case study of the Ritord watershed (Center-West France) Ecotoxicology 22:1186-1199 doi:10.1007/s10646-013-1106-5

Hetrick FM, Knittel MD, Fryer JL (1979) Increased susceptibility of rainbow trout to infectious hematopoietic necrosis virus after exposure to copper Applied and environmental microbiology 37:198-201 
Hynes H (1950) The food of fresh-water sticklebacks (Gasterosteus aculeatus and Pygosteus pungitius), with a review of methods used in studies of the food of fishes The journal of animal ecology 19:36-58

Ingram GA (1980) Substances involved in the natural resistance of fish to infection-A review Journal of Fish Biology 16:23-60 doi:10.1111/j.1095-8649.1980.tb03685.x

IRSN (2007) Inventaire national des sites miniers d'uranium.

Jolly S, Jaffal A, Delahaut L, Palluel O, Porcher J-M, Geffard A, Sanchez W, Betoulle S (2014) Effects of aluminium and bacterial lipopolysaccharide on oxidative stress and immune parameters in roach, Rutilus rutilus L Environmental Science and Pollution Research 21:13103-13117

Kelly JM, Janz DM (2009) Assessment of oxidative stress and histopathology in juvenile northern pike (Esox lucius) inhabiting lakes downstream of a uranium mill Aquat Toxicol 92:240-249 doi:10.1016/j.aquatox.2009.02.007

Kerambrun E, Henry F, Perrichon P, Courcot L, Meziane T, Spilmont N, Amara R (2012) Growth and condition indices of juvenile turbot, Scophthalmus maximus, exposed to contaminated sediments: effects of metallic and organic compounds Aquat Toxicol 108:130-140 doi:10.1016/j.aquatox.2011.07.016

Knittel M (1981) Susceptibility of steelhead trout Salmo gairdneri Richardson to redmouth infection Yersinia ruckeri following exposure to copper Journal of Fish Diseases 4:3340

Kumar PA, Rajagopal G (2003) Lipid peroxidation in erythrocytes of patients with type 2 diabetes mellitus Indian journal of clinical biochemistry 18:71-74

Laroche J, Quiniou L, Juhel G, Auffret M, Moraga D (2002) Genetic and physiological responses of flounder (Platichthys flesus) populations to chemical contamination in estuaries Environmental toxicology and chemistry 21:2705-2712

Le Guernic A, Sanchez W, Bado-Nilles A, Palluel O, Turies C, Chadili E, Cavalié I, Delahaut L, Adam-Guillermin C, Porcher JM, Geffard A, Betoulle S, Gagnaire B (submitted) In situ effects of metal contamination from former uranium mining sites on the threespined sticklebacks (Gasterosteus aculeatus, L.) health. Ecotoxicology

Ling KH, Sin YM, Lam TJ (1993) Effect of copper sulphate on ichthyophthiriasis (white spot disease) in goldfish (Carassius auratus) Aquaculture 118:23-35 doi:http://dx.doi.org/10.1016/0044-8486(93)90277-6

Lorin-Nebel C, Felten V, Blondeau-Bidet E, Grousset E, Amilhat E, Simon G, Biagianti S, Charmantier G (2013) Individual and combined effects of copper and parasitism on osmoregulation in the European eel Anguilla anguilla Aquatic toxicology 130-131:4150 doi:http://dx.doi.org/10.1016/j.aquatox.2012.11.018

Lushchak VI (2011) Environmentally induced oxidative stress in aquatic animals Aquatic toxicology 101:13-30

Maceda-Veiga A, Monroy M, Navarro E, Viscor G, de Sostoa A (2013) Metal concentrations and pathological responses of wild native fish exposed to sewage discharge in a Mediterranean river The Science of the total environment 449:9-19 doi:10.1016/j.scitotenv.2013.01.012

MacFarlane RD, Bullock GL, McLaughlin JJA (1986) Effects of five metals on susceptibility of striped bass to Flexibacter columnaris Transactions of the American Fisheries Society 115:227-231

Marques SM, Chaves S, Goncalves F, Pereira R (2013) Evaluation of growth, biochemical and bioaccumulation parameters in Pelophylax perezi tadpoles, following an in-situ acute exposure to three different effluent ponds from a uranium mine The Science of the total environment 445-446:321-328 doi:10.1016/j.scitotenv.2012.12.080 
Mitchelmore C, Chipman J (1998) DNA strand breakage in aquatic organisms and the potential value of the comet assay in environmental monitoring Mutation Research/Fundamental and Molecular Mechanisms of Mutagenesis 399:135-147

Moore MN, Lowe D, Köhler A (2004) Biological effects of contaminants: measurement of lysosomal membrane stability. vol 36. International Council for the Exploration of the Sea,

Münzing J (1963) The evolution of variation and distributional patterns in European populations of the three-spined stickleback, Gasterosteus aculeatus Evolution:320-332

Ndong D, Chen Y-Y, Lin Y-H, Vaseeharan B, Chen J-C (2007) The immune response of tilapia Oreochromis mossambicus and its susceptibility to Streptococcus iniae under stress in low and high temperatures Fish \& shellfish immunology 22:686-694

OECD (2000) Eleventh addendum to the OECD guidelines for testing of chemicals. OECD Publishing,

Ohkawa H, Ohishi N, Yagi K (1979) Assay for lipid peroxides in animal tissues by thiobarbituric acid reaction Analytical biochemistry 95:351-358

Oliva M, Jose Vicente J, Gravato C, Guilhermino L, Dolores Galindo-Riano M (2012) Oxidative stress biomarkers in Senegal sole, Solea senegalensis, to assess the impact of heavy metal pollution in a Huelva estuary (SW Spain): seasonal and spatial variation Ecotoxicology and environmental safety 75:151-162 doi:10.1016/j.ecoenv.2011.08.017

Paglia DE, Valentine WN (1967) Studies on the quantitative and qualitative characterization of erythrocyte glutathione peroxidase The Journal of laboratory and clinical medicine 70:158-169

Pandey S, Parvez S, Ansari RA, Ali M, Kaur M, Hayat F, Ahmad F, Raisuddin S (2008) Effects of exposure to multiple trace metals on biochemical, histological and ultrastructural features of gills of a freshwater fish, Channa punctata Bloch Chemicobiological interactions 174:183-192 doi:10.1016/j.cbi.2008.05.014

Paoletti F, Aldinucci D, Mocali A, Caparrini A (1986) A sensitive spectrophotometric method for the determination of superoxide dismutase activity in tissue extracts Analytical biochemistry 154:536-541

Pereira R, Antunes SC, Marques SM, Goncalves F (2008) Contribution for tier 1 of the ecological risk assessment of Cunha Baixa uranium mine (Central Portugal): I soil chemical characterization The Science of the total environment 390:377-386 doi:10.1016/j.scitotenv.2007.08.051

Playle RC (1998) Modelling metal interactions at fish gills Science of the Total Environment 219:147-163

Pottinger T, Carrick T, Yeomans W (2002) The three-spined stickleback as an environmental sentinel: effects of stressors on whole-body physiological indices Journal of Fish Biology 61:207-229

Qu R, Feng M, Wang X, Qin L, Wang C, Wang Z, Wang L (2014) Metal accumulation and oxidative stress biomarkers in liver of freshwater fish Carassius auratus following in vivo exposure to waterborne zinc under different $\mathrm{pH}$ values Aquat Toxicol 150:9-16 doi:10.1016/j.aquatox.2014.02.008

Regoli F, Nigro M, Orlando E (1998) Lysosomal and antioxidant responses to metals in the Antarctic scallop Adamussium colbecki Aquatic toxicology 40:375-392 doi:http://dx.doi.org/10.1016/S0166-445X(97)00059-3

Requintina PJ, Oxenkrug GF (2003) Differential effects of lipopolysaccharide on lipid peroxidation in $\mathrm{F} 344 \mathrm{~N}$, SHR rats and BALB/c mice, and protection of melatonin and NAS against its toxicity Ann N Y Acad Sci 993:325-333 
Roales RR, Perlmutter A (1977) The effects of sub-lethal doses of methylmercury and copper, applied singly and jointly, on the immune response of the blue gourami (Trichogaster trichopterus) to viral and bacterial antigens Archives of environmental contamination and toxicology 5:325-331 doi:10.1007/bf02220914

Robohm RA (1986) Paradoxical effects of cadmium exposure on antibacterial antibody responses in two fish species: Inhibition in cunners (Tautogolabrus adspersus) and enhancement in striped bass (Morone saxatilis) Veterinary immunology and immunopathology 12:251-262 doi:http://dx.doi.org/10.1016/0165-2427(86)90129-7

Rougier F, Menudier A, Bosgiraud C, Nicolas J (1996) Copper and zinc exposure of zebrafish, Brachydanio rerio (Hamilton-Buchaman): effects in experimental listeria infection Ecotoxicology and environmental safety 34:134-140

Roussel H, Joachim S, Lamothe S, Palluel O, Gauthier L, Bonzom JM (2007) A long-term copper exposure on freshwater ecosystem using lotic mesocosms: individual and population responses of three-spined sticklebacks (Gasterosteus aculeatus) Aquat Toxicol 82:272-280 doi:10.1016/j.aquatox.2007.02.018

Ruas CB, Carvalho Cdos S, de Araujo HS, Espindola EL, Fernandes MN (2008) Oxidative stress biomarkers of exposure in the blood of cichlid species from a metalcontaminated river Ecotoxicology and environmental safety 71:86-93 doi:10.1016/j.ecoenv.2007.08.018

Sanchez-Dardon J, Voccia I, Hontela A, Chilmonczyk S, Dunier M, Boermans H, Blakley B, Fournier M (1999) Immunomodulation by heavy metals tested individually or in mixtures in rainbow trout (Oncorhynchus mykiss) exposed in vivo Environmental toxicology and chemistry 18:1492-1497

Sanchez W, Ait-Aissa S, Palluel O, Ditche JM, Porcher JM (2007) Preliminary investigation of multi-biomarker responses in three-spined stickleback (Gasterosteus aculeatus L.) sampled in contaminated streams Ecotoxicology 16:279-287 doi:10.1007/s10646-0060131-z

Sanchez W, Katsiadaki I, Piccini B, Ditche JM, Porcher JM (2008a) Biomarker responses in wild three-spined stickleback (Gasterosteus aculeatus L.) as a useful tool for freshwater biomonitoring: a multiparametric approach Environment international 34:490-498 doi:10.1016/j.envint.2007.11.003

Sanchez W, Palluel O, Meunier L, Coquery M, Porcher JM, Ait-Aissa S (2005) Copperinduced oxidative stress in three-spined stickleback: relationship with hepatic metal levels Environmental toxicology and pharmacology 19:177-183 doi:10.1016/j.etap.2004.07.003

Sanchez W, Piccini B, Ditche JM, Porcher JM (2008b) Assessment of seasonal variability of biomarkers in three-spined stickleback (Gasterosteus aculeatus L.) from a low contaminated stream: implication for environmental biomonitoring Environment international 34:791-798 doi:10.1016/j.envint.2008.01.005

Santos R, Palos-Ladeiro M, Besnard A, Porcher JM, Bony S, Sanchez W, Devaux A (2013) Relationship between DNA damage in sperm after ex vivo exposure and abnormal embryo development in the progeny of the three-spined stickleback Reprod Toxicol 36:6-11 doi:10.1016/j.reprotox.2012.11.004

Saxena M, Gopal K, Jones W, Ray P (1992) Immune responses to Aeromonas hydrophila in cat fish (Heteropneustis fossilis) exposed to cadmium and hexachlorocyclohexane Bulletin of environmental contamination and toxicology 48:194-201

Sevcikova M, Modra H, Slaninova A, Svobodova Z (2011) Metals as a cause of oxidative stress in fish: a review Vet Med 56:537-546

Sewerynek E, Melchiorri D, Reiter RJ, Ortiz GG, Lewinski A (1995) Lipopolysaccharideinduced hepatotoxicity is inhibited by the antioxidant melatonin European Journal of 
Pharmacology: Environmental Toxicology and Pharmacology 293:327-334 doi:http://dx.doi.org/10.1016/0926-6917(95)90052-7

Sheir SK, Handy RD (2010) Tissue Injury and Cellular Immune Responses to Cadmium Chloride Exposure in the Common Mussel Mytilus edulis: Modulation by Lipopolysaccharide Archives of environmental contamination and toxicology 59:602613 doi:10.1007/s00244-010-9502-9

Sindayigaya E, Van Cauwenbergh R, Robberecht H, Deelstra H (1994) Copper, zinc, manganese, iron, lead, cadmium, mercury and arsenic in fish from Lake Tanganyika, Burundi Science of the Total Environment 144:103-115

Spry DJ, Wiener JG (1991) Metal bioavailability and toxicity to fish in low-alkalinity lakes: A critical review Environmental Pollution doi:http://dx.doi.org/10.1016/0269-7491(91)90034-T

Stadtman E, Oliver C (1991) Metal-catalyzed oxidation of proteins. Physiological consequences J Biol Chem 266:2005-2008

Stolen JS, Fletcher TC (1994) Modulators of Fish Immune Responses. Volume 1. Models for Environmental Toxicology/Biomarkers Immunostimulators. DTIC Document,

Sugino K, Dohi K, Yamada K, Kawasaki T (1987) The role of lipid peroxidation in endotoxin-induced hepatic damage and the protective effect of antioxidants Surgery 101:746-752

Swain P, Nayak SK, Nanda PK, Dash S (2008) Biological effects of bacterial lipopolysaccharide (endotoxin) in fish: a review Fish \& shellfish immunology 25:191201 doi:10.1016/j.fsi.2008.04.009

Vandeputte C, Guizon I, Genestie-Denis I, Vannier B, Lorenzon G (1994) A microtiter plate assay for total glutathione and glutathione disulfide contents in cultured/isolated cells: performance study of a new miniaturized protocol Cell biology and toxicology 10:415-421

Vieira MC, Torronteras R, Cordoba F, Canalejo A (2012) Acute toxicity of manganese in goldfish Carassius auratus is associated with oxidative stress and organ specific antioxidant responses Ecotoxicology and environmental safety 78:212-217 doi:10.1016/j.ecoenv.2011.11.015

WaagbØ R (1994) The impact of nutritional factors on the immune system in Atlantic salmon, Salmo salar L.: a review Aquaculture Research 25:175-197 doi:10.1111/j.13652109.1994.tb00573.x

Wirzinger G, Weltje L, Gercken J, Sordyl H (2007) Genotoxic damage in field-collected three-spined sticklebacks (Gasterosteus aculeatus L.): a suitable biomonitoring tool? Mutation research 628:19-30 doi:10.1016/j.mrgentox.2006.11.011

Wootton RJ (1984) A functional biology of sticklebacks. Univ of California Press,

Xiang L-X, Peng B, Dong W-R, Yang Z-F, Shao J-Z (2008) Lipopolysaccharide induces apoptosis in $<\mathrm{i}>$ Carassius auratus $</ \mathrm{i}>$ lymphocytes, a possible role in pathogenesis of bacterial infection in fish Developmental \& Comparative Immunology 32:992-1001

Yadav KK, Trivedi SP (2009) Sublethal exposure of heavy metals induces micronuclei in fish, Channa punctata 77:1495-1500 doi:10.1016/j.chemosphere.2009.10.022

Zelikoff JT (1993) Metal pollution-induced immunomodulation in fish Annual Review of Fish Diseases 3:305-325

\section{Figure legends}


Fig. 1: Experimental design for the preliminary experiment realised in the laboratory. D: day when injection were made; MS222: tricaine methanesulfonate at $0.1 \mathrm{~g} / \mathrm{L} ;$ LPS: lipopolysaccharides; PBS: phosphate buffer saline.

Fig. 2: Localisation of studied ponds in the Haute-Vienne department. Stars indicate the ponds and "U" indicates the discharges coming from mining sites in the Pontabrier pond. The figure also shows close-ups of the three ponds used in this study.

Fig. 3: Experimental design for the in situ experiment. D: day when injection were made; MS222: tricaine methanesulfonate at $0.1 \mathrm{~g} / \mathrm{L}$; LPS: lipopolysaccharides; PBS: phosphate buffer saline.

Table 1: Physical and chemical characteristics of ponds. Data are means \pm standard deviation ( $n=17$ for temperature; $n=3$ for metals concentrations; $n=2$ for anions / cations; $n=1$ for conductivity and $\mathrm{pH}$ ). Difference between ponds is indicated by different letters for $p \leq 0.05$ with $\mathrm{a}>\mathrm{b}>\mathrm{c}$. DL: detection limit; T min: mean minimal temperature; T max: mean maximal temperature; $\Delta \mathrm{d} / \mathrm{n}$ : day/night temperature delta; $\mathrm{C}$ : conductivity; DO: dissolved oxygen; $\mathrm{C}$ inorg: total inorganic carbon; $\mathrm{C}$ org: total organic carbon; PCBs: polychlorinated biphenyls; PAHs: polycyclic aromatic hydrocarbons; VOCs: volatile organic compounds; 2.4D: 2.4Dichlorophenoxyacetic acid.

Table 2: Biomarker responses in three-spined sticklebacks caged in the Haute-Vienne ponds from according to LPS or PBS injections. Values are means \pm standard error of the mean $(n=$ 15). Inside each injection condition, difference between ponds is indicated by different letters for $p \leq 0.05$ with $\mathrm{a}>\mathrm{b}>\mathrm{c}$. Bolded means show a significant difference between LPS and PBS condition for the same pond. K: condition factor; HSI: hepato-somatic index; Necrosis: leucocyte necrosis; Apoptosis: leucocyte apoptosis; Lympho: lymphocyte percentage; LMI: lysosomal membrane integrity; Pg: phagocytic capacity; ROS b.: ROS basal level; ROS a.: ROS activated; SI: stimulation index of respiratory burst; Gr: glutathione reductase; GPx: glutathione peroxidase; GSH: total glutathione; GST: Glutathione-S-transferase; CAT: catalase; SOD: superoxide dismutase; TBARS: thiobarbituric acid reactive substances; DNA: DNA damage; FU: fluorescence unit. 
Table 3: Interaction of effects between the chemical stress (ponds) and the biological stress (injection). Only results with a significant effect of one stress or their interaction on biomarker are noted $(\bullet: 0.05>p \geq 0.10 ; *: 0.01>p \geq 0.05$; **: $0.001>p \geq 0.01 ; * * *: p \leq 0.001) . \mathrm{K}$ : condition factor; HSI: hepato-somatic index; Necrosis: leucocyte necrosis; Apoptosis: leucocyte apoptosis; Lympho: lymphocyte percentage; LMI: lysosomal membrane integrity; Pg: phagocytic capacity; ROS b.: ROS basal level; ROS a.: ROS activated; SI: stimulation index of respiratory burst; Gr: glutathione reductase; GPx: glutathione peroxidase; GSH: total glutathione; GST: Glutathione-S-transferase; CAT: catalase; SOD: superoxide dismutase; TBARS: thiobarbituric acid reactive substances; DNA: DNA damages.

Table 4: Comparison of LPS effects on biomarkers between the laboratory and the in situ experiments. Each effect (increase: $\nearrow$ or decrease: $\searrow$ ) is followed by its significance (S: significant effect; NS: non-significant effect). For some caging conditions, no effect was observed (Ø). Pg: phagocytic capacity; ROS a.: ROS activated; SI: stimulation index of respiratory burst; GSH: total glutathione; GST: Glutathione-S-transferase; CAT: catalase.

Fig. 4: PCA results representing individuals grouped according to pond (A) or to biological stress (B) (illustrative variables). Principal components (CP 1 \& CP 2) are constructed from all biomarkers analysed. The number of selected dimensions is 2. Values between parentheses are the eigenvalues for each axis, followed by the inertia values. The table below summarizes the contributions to the axes of each variable (percentage). K: condition factor; HSI: hepatosomatic index; Necrosis: leucocyte necrosis; Apoptosis: leucocyte apoptosis; Lympho: lymphocyte percentage; Pg: phagocytic capacity; ROS b.: ROS basal; ROS a.: ROS activated; SI: stimulation index of respiratory burst; Gr: glutathione reductase; GPx: glutathione peroxidase; GSH: total glutathione; GST: Glutathione-S-transferase; CAT: catalase; SOD: superoxide dismutase; TBARS: thiobarbituric acid reactive substances; DNA: DNA damage.

Annex 1: Effects of LPS injections on fish biomarkers obtained during the preliminary experiment. Underlined values for PBS and anaesthesia control conditions are significantly different, as well as bolded values between PBS and injection control conditions. Inside of each sampling time, means with different letters are significantly different from each other (a $>\mathrm{b}>\mathrm{c} / \mathrm{e}>\mathrm{f}>\mathrm{g} / \mathrm{i}>\mathrm{j}>\mathrm{k} / \mathrm{m}>\mathrm{n}>\mathrm{o})(\alpha=5 \%)$. D: injection day; Necrosis: leucocyte necrosis; Apoptosis: leucocyte apoptosis; Lympho.: lymphocyte percentage; LMI: lysosomal membrane integrity; Pg.: phagocytic capacity; ROS b.: ROS basal level; ROS a.: ROS 
activated level; SI: stimulation index of respiratory burst; GSH: total glutathione; Gr: glutathione reductase; GPx: glutathione peroxidase; GST: glutathione-S-tranferase; CAT: catalase; SOD: superoxide dismutase; TBARS: thiobarbituric acid reactive susbtances; FU: fluorescence units.

Annex 2: Temperature $\left({ }^{\circ} \mathrm{C}\right)$ inside cages according to ponds and to experiment date. Temperature was recorded each hour using probes.

Annex 3: Transmission electron microscopy observations of leucocyte phagocytosis from stickleback spleen. Black circles represent fluorescent microbeads ingested. A, B and C: granulocytes; D: lymphocyte. 


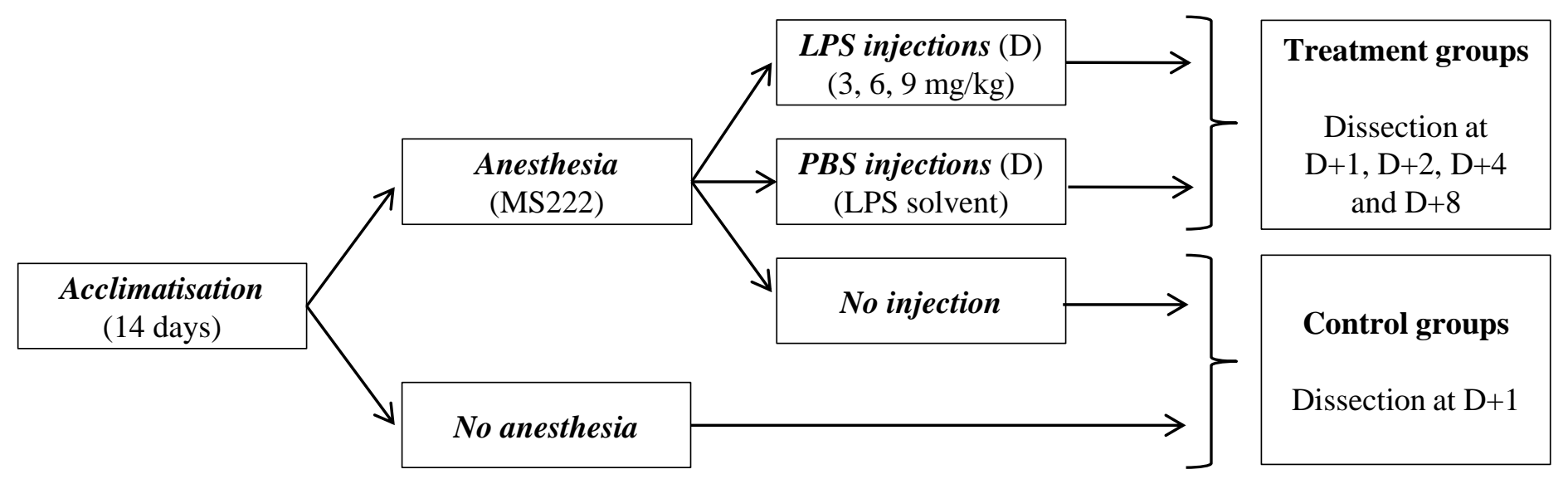

$n=10$ per treatment (LPS, PBS and control) and per sampling time 


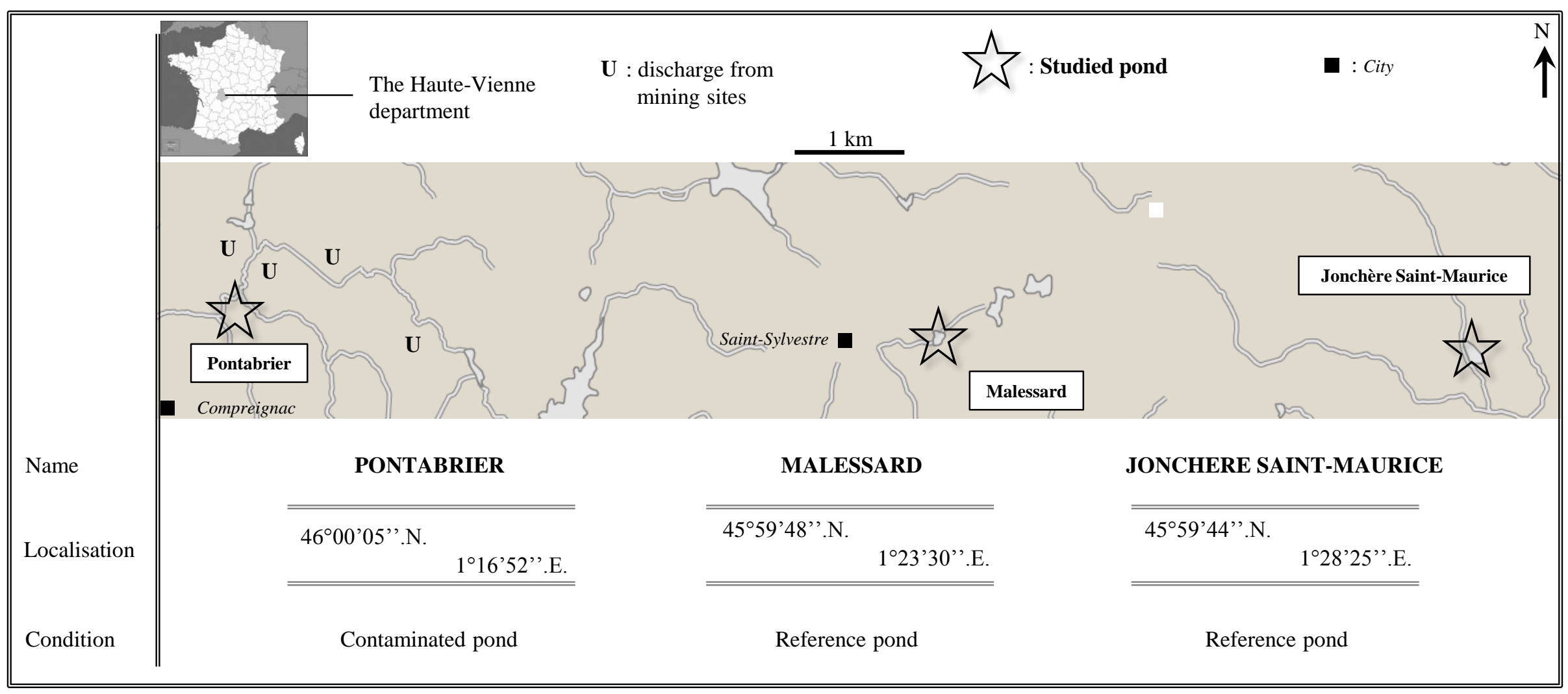



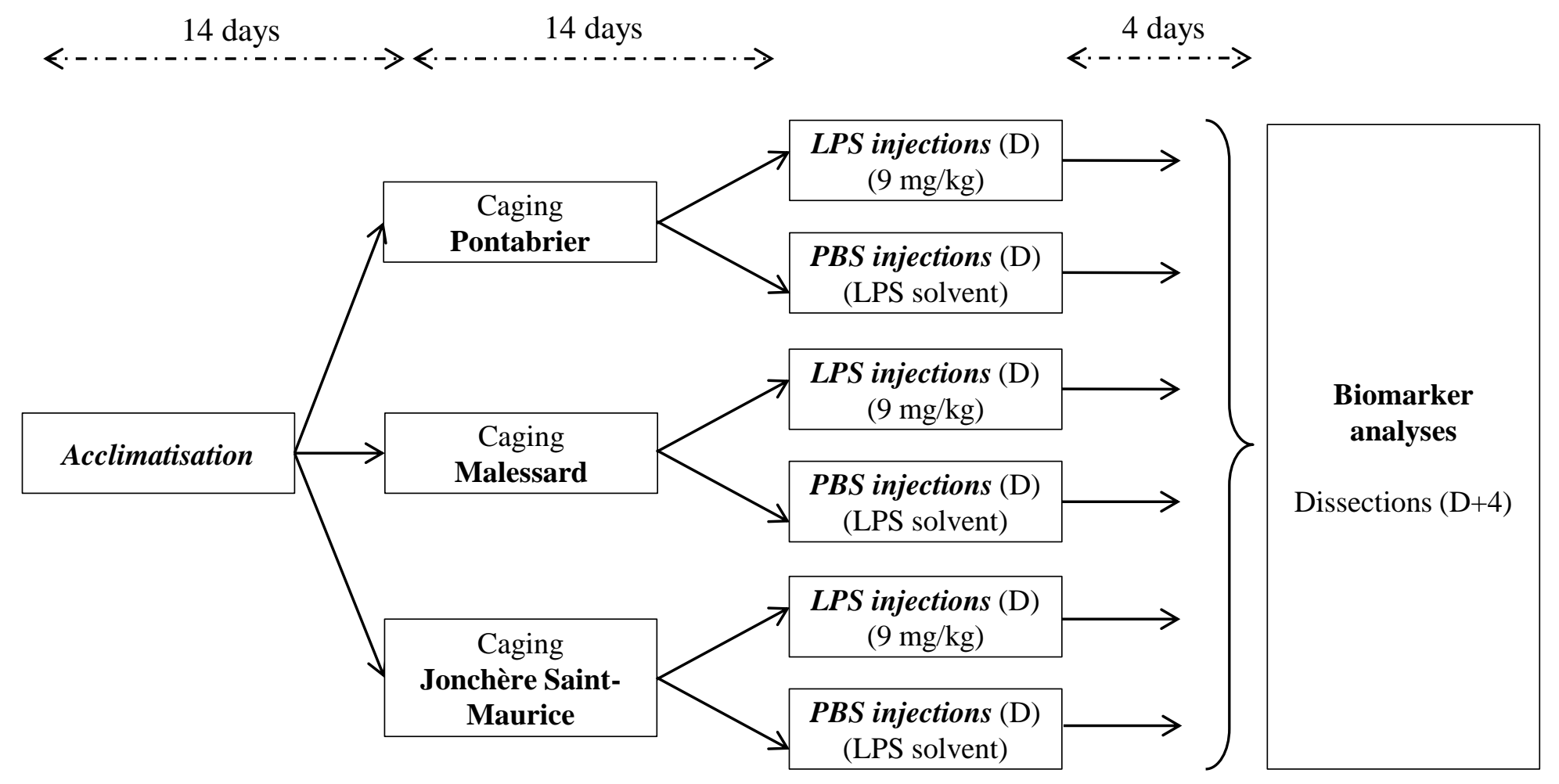

$n=15$ per treatment (LPS and PBS) and per pond 


\section{Annex 1:}

\begin{tabular}{|c|c|c|c|c|c|c|c|c|c|c|c|c|c|c|c|c|c|c|c|c|c|c|c|c|c|c|c|c|c|c|c|c|}
\hline \multirow{2}{*}{$\begin{array}{c}\text { Sampling } \\
\text { time }\end{array}$} & \multirow{2}{*}{$\begin{array}{c}\text { Injection } \\
\text { conditions }\end{array}$} & \multicolumn{3}{|c|}{ Necrosis (\%) } & \multicolumn{4}{|c|}{ Apoptosis (\%) } & \multicolumn{4}{|c|}{ Lympho. (\%) } & \multicolumn{4}{|c|}{ LMI (FU) } & \multicolumn{4}{|c|}{$\operatorname{Pg}(\%)$} & \multicolumn{4}{|c|}{ ROS b. (FU) } & \multicolumn{4}{|c|}{ ROS a. (FU) } & \multicolumn{4}{|c|}{ SI } \\
\hline & & Mean & $\pm \mathrm{SD}$ & & Mean & \pm & SD & & Mean & \pm & SD & & Mean & \pm & $\mathrm{SD}$ & & Mean & \pm & & & Mean & \pm & SD & & Mean & & SD & & Mean & $\pm S$ & $\mathrm{SD}$ & \\
\hline \multirow{6}{*}{$D+1$} & Anaesthesia control & 2.45 & \pm 0.82 & & 6.46 & \pm & 1.67 & & $\underline{80.63}$ & \pm & 5.10 & & 177.26 & \pm & 42.43 & & $\underline{16.14}$ & \pm & 7.44 & & 3.73 & \pm & 1.40 & & $\underline{2.38}$ & \pm & 0.72 & & 0.66 & \pm 0 & 0.17 & \\
\hline & Injection control & 3.24 & \pm 1.40 & & 6.58 & \pm & 2.12 & & 84.43 & \pm & 3.85 & & 155.04 & \pm & 32.16 & & 9.39 & \pm & 4.06 & & 4.44 & \pm & 1.14 & & 3.97 & \pm & 2.58 & & 0.84 & \pm 0 & 0.32 & \\
\hline & PBS & 2.11 & \pm 0.73 & $\mathrm{~b}$ & 5.98 & \pm & 1.65 & $\mathrm{c}$ & 84.36 & \pm & 4.13 & $\mathrm{ab}$ & 198.59 & \pm & 45.64 & $\mathrm{a}$ & 11.50 & \pm & 5.87 & $\mathrm{~b}$ & 3.94 & \pm 2 & 2.66 & $\mathrm{~b}$ & $\underline{8.44}$ & \pm & 4.19 & $\mathrm{a}$ & 2.25 & \pm 0 & 0.67 & $\mathrm{a}$ \\
\hline & LPS (3 mg/kg) & 2.38 & \pm 0.57 & $\mathrm{~b}$ & 7.11 & \pm & 1.81 & $\mathrm{bc}$ & 84.65 & \pm & 2.98 & a & 166.85 & \pm & 23.97 & $\mathrm{~b}$ & 12.72 & \pm & 1.77 & $\mathrm{a}$ & 4.71 & \pm & 4.14 & $\mathrm{ab}$ & $8 ; 17$ & \pm & 3.91 & $\mathrm{a}$ & 1.96 & \pm 0 & 0.71 & $\mathrm{a}$ \\
\hline & LPS (6 mg/kg) & 3.30 & \pm 0.84 & $\mathrm{a}$ & 10.14 & \pm & 1.95 & $\mathrm{a}$ & 81.80 & \pm & 3.64 & $\mathrm{ab}$ & 138.14 & \pm & 65.64 & $\mathrm{~b}$ & 11.75 & \pm & 2.06 & $\mathrm{ab}$ & 3.88 & \pm & 1.83 & $\mathrm{~b}$ & 8.79 & \pm & 2.62 & $\mathrm{a}$ & 2.38 & \pm 0 & 0.83 & $\mathrm{a}$ \\
\hline & LPS $(9 \mathrm{mg} / \mathrm{kg})$ & 3.40 & \pm 1.34 & a & 8.21 & \pm & 1.74 & $\mathrm{~b}$ & 81.02 & \pm & 4.36 & b & 215.60 & \pm & 35.57 & a & 13.95 & \pm & 2.90 & a & 8.68 & \pm & 4.52 & a & 8.61 & \pm & 1.47 & a & 1.51 & \pm 1 & 1.14 & a \\
\hline \multirow{4}{*}{$D+2$} & PBS & 2.89 & \pm 0.71 & $\mathrm{f}$ & 6.18 & \pm & 1.25 & f & 84.38 & \pm & 3.49 & $\mathrm{e}$ & 173.25 & \pm & 13.18 & f & $\underline{7.56}$ & \pm & 2.81 & $\mathrm{~g}$ & 4.28 & \pm & 1.57 & $\mathrm{e}$ & $\underline{5.37}$ & \pm & 3.23 & $\mathrm{~g}$ & 1.18 & \pm 0 & 0.32 & $\mathrm{~g}$ \\
\hline & LPS ( $3 \mathrm{mg} / \mathrm{kg})$ & 2.86 & \pm 0.59 & $\mathrm{f}$ & 6.43 & \pm & 2.13 & $\mathrm{f}$ & 83.96 & \pm & 3.86 & $\mathrm{e}$ & 160.02 & \pm & 15.95 & $\mathrm{fg}$ & 14.67 & \pm & 2.74 & $\mathrm{f}$ & 4.42 & \pm & 1.16 & $\mathrm{e}$ & 8.19 & \pm & 1.78 & ef & 1.92 & \pm 0 & 0.41 & $\mathrm{f}$ \\
\hline & LPS (6 mg/kg) & 4.03 & \pm 1.18 & $\mathrm{e}$ & 9.05 & \pm & 2.59 & $\mathrm{e}$ & 77.13 & \pm & 3.47 & $\mathrm{f}$ & 144.25 & \pm & 17.80 & $\mathrm{~g}$ & 14.94 & \pm & 2.39 & ef & 3.80 & \pm & 1.51 & $\mathrm{e}$ & 7.96 & \pm & 0.90 & $\mathrm{fg}$ & 2.43 & \pm 0 & 0.45 & $\mathrm{e}$ \\
\hline & LPS $(9 \mathrm{mg} / \mathrm{kg})$ & 3.14 & \pm 0.72 & ef & 7.31 & \pm & 1.10 & ef & 82.32 & \pm & 2.61 & e & 197.79 & \pm & 33.71 & e & 16.55 & \pm & 2.75 & e & 5.98. & \pm & 3.31 & e & 11.44 & & 3.06 & e & 2.23 & \pm 0 & 0.87 & ef \\
\hline \multirow{4}{*}{$D+4$} & PBS & 2.66 & \pm 0.48 & $\mathrm{i}$ & 7.63 & \pm & 0.84 & $\mathrm{i}$ & $\underline{85.09}$ & \pm & 3.44 & $\mathrm{i}$ & 157.99 & \pm & 20.52 & $\mathrm{j}$ & & & & & 4.39 & \pm & 1.05 & $\mathrm{i}$ & $\underline{3.48}$ & \pm & 1.22 & $\mathrm{j}$ & 0.79 & \pm 0 & 0.18 & $\mathrm{k}$ \\
\hline & LPS ( $3 \mathrm{mg} / \mathrm{kg}$ ) & 3.42 & \pm 1.08 & $\mathrm{i}$ & 6.98 & \pm & 1.26 & $\mathrm{ij}$ & 82.32 & \pm & 4.65 & $\mathrm{i}$ & 157.38 & \pm & 27.23 & $\mathrm{j}$ & & & & & 3.78 & \pm & 1.16 & $\mathrm{ij}$ & 4.90 & \pm & 2.54 & $\mathrm{ij}$ & 1.24 & \pm 0 & 0.33 & $\mathrm{j}$ \\
\hline & LPS (6 mg/kg) & 3.21 & \pm 1.34 & $\mathrm{i}$ & 9.29 & \pm & 3.60 & $\mathrm{i}$ & 79.90 & \pm & 8.24 & i & 141.79 & \pm & 38.26 & $\mathrm{j}$ & & & & & 3.27 & \pm & 0.92 & $\mathrm{j}$ & 4.11 & \pm & 2.37 & $\mathrm{j}$ & 1.18 & \pm 0 & 0.41 & $\mathrm{j}$ \\
\hline & LPS $(9 \mathrm{mg} / \mathrm{kg})$ & 2.86 & \pm 0.68 & i & 6.63 &. \pm & 0.95 & $\mathrm{j}$ & 84.98 & \pm & 3.37 & $\mathrm{i}$ & 205.52 & \pm & 30.13 & $\mathrm{i}$ & & & & & 3.12. & $\pm \ldots$ & 0.88 & $\mathrm{j}$ & 6.28 & \pm & 3.53 & $\mathrm{i}$ & 2.09 & \pm 0 & 0.79 & $\mathrm{i}$ \\
\hline \multirow{3}{*}{$D+8$} & PBS & 2.32 & \pm 0.65 & $\mathrm{n}$ & 6.81 & \pm & 1.81 & $\mathrm{n}$ & $\underline{87.35}$ & \pm & 2.54 & $\mathrm{~m}$ & 183.08 & \pm & 30.24 & $\mathrm{~m}$ & 10.00 & \pm & 5.68 & $\mathrm{~m}$ & 4.56 & \pm & 0.94 & $\mathrm{~m}$ & $\underline{2.87}$ & \pm & 0.47 & $\mathrm{~m}$ & 0.63 & \pm 0 & 0.08 & 0 \\
\hline & LPS ( $3 \mathrm{mg} / \mathrm{kg}$ ) & 3.06 & \pm 0.71 & $\mathrm{~m}$ & 8.26 & \pm & 1.09 & $\mathrm{~m}$ & 85.53 & \pm & 2.66 & $\mathrm{n}$ & 201.16 & \pm & 50.52 & $\mathrm{~m}$ & 9.30 & \pm & 5.29 & $\mathrm{~m}$ & 3.51 & \pm & 0.44 & $\mathrm{n}$ & 3.02 & \pm & 0.48 & $\mathrm{~m}$ & 0.85 & \pm 0 & 0.05 & $\mathrm{n}$ \\
\hline & LPS $(9 \mathrm{mg} / \mathrm{kg})$ & 2.97 & \pm 0.67 & $\mathrm{~m}$ & 8.54 & \pm & 1.37 & $\mathrm{~m}$ & 84.30 & \pm & 5.08 & $\mathrm{n}$ & 191.81 & \pm & 34.92 & $\mathrm{~m}$ & 9.41 & \pm & 3.78 & $\mathrm{~m}$ & 2.74 & \pm & 0.15 & $\mathrm{o}$ & 2.70 & \pm & 0.12 & $\mathrm{~m}$ & 0.98 & \pm 0 & 0.05 & $\mathrm{~m}$ \\
\hline Sampling & Injection & GSH $(\mu$ & $\mathrm{umol} / \mathrm{g}$ to & prot) & Gr & $\mathrm{U} / \mathrm{g}$ & tot pr & & GPx & $(\mathrm{U} / \mathrm{g}$ & tot pro & & GST & $(\mathrm{U} / \mathrm{g}$ & g tot pr & & $\operatorname{CAT}(10$ & $03 \times \mathrm{C}$ & $\mathrm{U} / \mathrm{g}$ tot & prot) & SOD & $(\mathrm{U} / \mathrm{g}$ & tot pr & & & BAR: & QS (FU) & & & & & \\
\hline & conditions & Mean & $\pm \mathrm{SD}$ & & Mean & \pm & $\mathrm{SD}$ & & Mean & \pm & $\mathrm{SD}$ & & Mean & \pm & SD & & Mean & \pm & SD & & Mean & \pm & & & Mean & \pm & $\mathrm{SD}$ & & & & & \\
\hline & Anaesthesia control & $\underline{19.58}$ & \pm 7.81 & & 10.61 & \pm & 8.91 & & 88.06 & \pm & 103.36 & & 908.10 & \pm & 440.23 & & $\underline{713.96}$ & \pm & 477.61 & & $\underline{821.23}$ & \pm & 518.26 & & $\underline{15,463}$ & \pm & 7,183 & & & & & \\
\hline & Injection control & 16.28 & \pm 3.49 & & 8.88 & \pm & 5.47 & & 134.63 & \pm & 104.96 & & 631.75 & \pm & 183.30 & & 818.55 & \pm & 290.48 & & 475.95 & \pm & 181.79 & & 13,604 & \pm & 7,289 & & & & & \\
\hline & PBS & 12.70 & \pm 6.82 & $\mathrm{a}$ & 10.22 & \pm & 3.57 & $\mathrm{a}$ & 157.52 & \pm & 138.30 & $a$ & 675.69 & \pm & 268.74 & $+a$ & 817.07 & \pm & 297.39 & $\mathrm{a}$ & $\underline{369.28}$ & \pm 2 & 296.89 & $\mathrm{a}$ & 11,874 & \pm & 4,080 & $\mathrm{a}$ & & & & \\
\hline & LPS ( $3 \mathrm{mg} / \mathrm{kg}$ ) & 11.67 & \pm 3.66 & $\mathrm{a}$ & 8.98 & \pm & 3.99 & $\mathrm{a}$ & 96.53 & \pm & 85.57 & $\mathrm{a}$ & 614.38 & \pm & 236.68 & a & 667.73 & \pm & 376.36 & $\mathrm{a}$ & 349.96 & \pm & 232.96 & $\mathrm{a}$ & 9,414 & \pm & 3,136 & $\mathrm{a}$ & & & & \\
\hline & LPS (6 mg/kg) & 9.51 & \pm 2.88 & $\mathrm{ab}$ & 7.37 & \pm & 3.99 & a & 99.11 & \pm & 67.89 & $\mathrm{a}$ & 561.07 & \pm & 183.03 & a & 766.72 & \pm & 305.31 & $\mathrm{a}$ & 631.79 & \pm & 346.42 & a & 9,205 & \pm & 4,113 & $\mathrm{a}$ & & & & \\
\hline & LPS $(9 \mathrm{mg} / \mathrm{kg})$ & 6.88 & $\begin{array}{r} \pm .03 \\
\end{array}$ & $\mathrm{~b}$ & 7.21 & \pm & 4.33 & a & 58.49 & \pm & 42.25 & a & 515.49 & \pm & 116.79 & a & 734.19 & \pm & 260.39 & a & 570.79 & \pm & 260.33 & a & 10,014 & & 3,896 & a & & & & \\
\hline & PBS & $\underline{12.80}$ & \pm 5.82 & $\mathrm{e}$ & 9.27 & \pm & 5.34 & $\mathrm{e}$ & 126.31 & \pm & 86.39 & $\mathrm{e}$ & 572.70 & \pm & 299.80 & $\mathrm{e}$ & 966.89 & \pm & 463.79 & $\mathrm{e}$ & $\underline{346.13}$ & \pm & 266.37 & ef & 11,470 & \pm & 5,481 & $\mathrm{e}$ & & & & \\
\hline $\mathrm{D}+2$ & LPS ( $3 \mathrm{mg} / \mathrm{kg})$ & 10.62 & \pm 3.26 & $\mathrm{e}$ & 6.89 & \pm & 2.65 & $\mathrm{e}$ & 90.30 & \pm & 65.46 & $\mathrm{e}$ & 527.06 & \pm & 180.55 & $\mathrm{e}$ & 560.69 & \pm & 266.35 & $\mathrm{f}$ & 302.75 & \pm & 257.53 & $\mathrm{f}$ & 10,654 & \pm & 4,529 & $\mathrm{e}$ & & & & \\
\hline & LPS (6 mg/kg) & 13.30 & \pm 8.26 & $\mathrm{e}$ & 8.05 & \pm & 3.06 & $\mathrm{e}$ & 90.59 & \pm & 55.87 & $\mathrm{e}$ & 630.57 & \pm & 302.37 & $\mathrm{e}$ & 979.10 & \pm & 276.06 & $\mathrm{e}$ & 674.62 & \pm & 406.05 & $\mathrm{e}$ & 9,607 & \pm & 2,369 & $\mathrm{e}$ & & & & \\
\hline & LPS $(9 \mathrm{mg} / \mathrm{kg})$ & 9.57 & $\begin{array}{r} \pm .94 \\
\end{array}$ & $\mathrm{e}$ & 7.84 & \pm & 5.01 & $\mathrm{e}$ & 105.83 & \pm & 126.63 & $\mathrm{e}$ & 468.59 & \pm & 262.98 & $\mathrm{e}$ & 903.23 & \pm & 545.15 & ef & 446.82 & \pm & 387.24 & ef & 9,958 & & 3,695 & $\mathrm{e}$ & & & & \\
\hline & PBS & 13.81 & \pm 5.64 & $\mathrm{i}$ & 7.29 & \pm & 3.21 & $\mathrm{i}$ & 123.85 & \pm & 68.21 & $\mathrm{ij}$ & 722.39 & \pm & 315.46 & $\mathrm{ij}$ & $\underline{1287.13}$ & \pm & 313.91 & $\mathrm{i}$ & 651.21 & \pm & 415.59 & $\mathrm{i}$ & 11,331 & \pm & 5,094 & $\mathrm{i}$ & & & & \\
\hline$D+4$ & LPS ( $3 \mathrm{mg} / \mathrm{kg})$ & 12.45 & \pm 5.98 & i & 7.03 & \pm & 4.76 & $\mathrm{i}$ & 61.39 & \pm & 78.75 & $\mathrm{j}$ & 659.93 & \pm & 337.96 & ij & 717.75 & \pm & 563.96 & $\mathrm{j}$ & 619.05 & \pm & 480.00 & $\mathrm{i}$ & 11,626 & \pm & 4,346 & $\mathrm{i}$ & & & & \\
\hline & LPS (6 mg/kg) & 13.32 & \pm 4.26 & i & 9.98 & \pm & 3.28 & $\mathrm{i}$ & 167.57 & \pm & 82.61 & $\mathrm{i}$ & 857.75 & \pm & 391.79 & $\mathrm{i}$ & 1198.10 & \pm & 440.79 & $\mathrm{i}$ & 790.62 & \pm & 765.66 & $\mathrm{i}$ & 10,076 & \pm & 3,153 & $\mathrm{i}$ & & & & \\
\hline & LPS $(9 \mathrm{mg} / \mathrm{kg})$ & 6.12 & \pm 3.83 & $\mathrm{j}$ & 7.98 & \pm & 4.99 & $\mathrm{i}$ & 110.01 & \pm & 144.5 & $\mathrm{ij}$ & 456.99 & \pm & 250.96 & $\mathrm{j}$ & 693.07 & \pm & 409.41 & $\mathrm{j}$ & 454.24 & \pm & 326.78 & $\mathrm{i}$ & 8,671 & \pm & 3,304 & $\mathrm{i}$ & & & & \\
\hline & PBS & $\underline{12.86}$ & \pm 5.56 & $\mathrm{~m}$ & 8.69 & \pm & 4.78 & $\mathrm{~m}$ & 113.48 & \pm & 74.85 & $\mathrm{~m}$ & 583.60 & \pm & 227.58 & $\mathrm{~m}$ & 908.34 & \pm & 474.81 & $\mathrm{~m}$ & 623.63 & \pm & 339.33 & $\mathrm{~m}$ & $\underline{10.900}$ & \pm & 3,487 & $\mathrm{~m}$ & & & & \\
\hline$D+8$ & LPS ( $3 \mathrm{mg} / \mathrm{kg})$ & 9.45 & \pm 4.07 & $\mathrm{mn}$ & 6.87 & \pm & 3.47 & $\mathrm{~m}$ & 112.65 & \pm & 104.43 & $\mathrm{mn}$ & 516.39 & \pm & 217.49 & $\mathrm{~m}$ & 797.52 & \pm & 438.74 & $\mathrm{~m}$ & 380.58 & \pm & 186.13 & $\mathrm{mn}$ & 8,515 & \pm & 1,675 & $\mathrm{~m}$ & & & & \\
\hline & LPS $(9 \mathrm{mg} / \mathrm{kg})$ & 6.79 & \pm 3.76 & $\mathrm{n}$ & 3.42 & \pm & 1.72 & $\mathrm{n}$ & 41.71 & \pm & 37.14 & $\mathrm{n}$ & 429.67 & \pm & 210.50 & $\mathrm{~m}$ & 663.26 & \pm & 345.47 & $\mathrm{~m}$ & 220.00 & \pm & 135.77 & $\mathrm{n}$ & 8,883 & \pm & 3,082 & $\mathrm{~m}$ & & & & \\
\hline
\end{tabular}




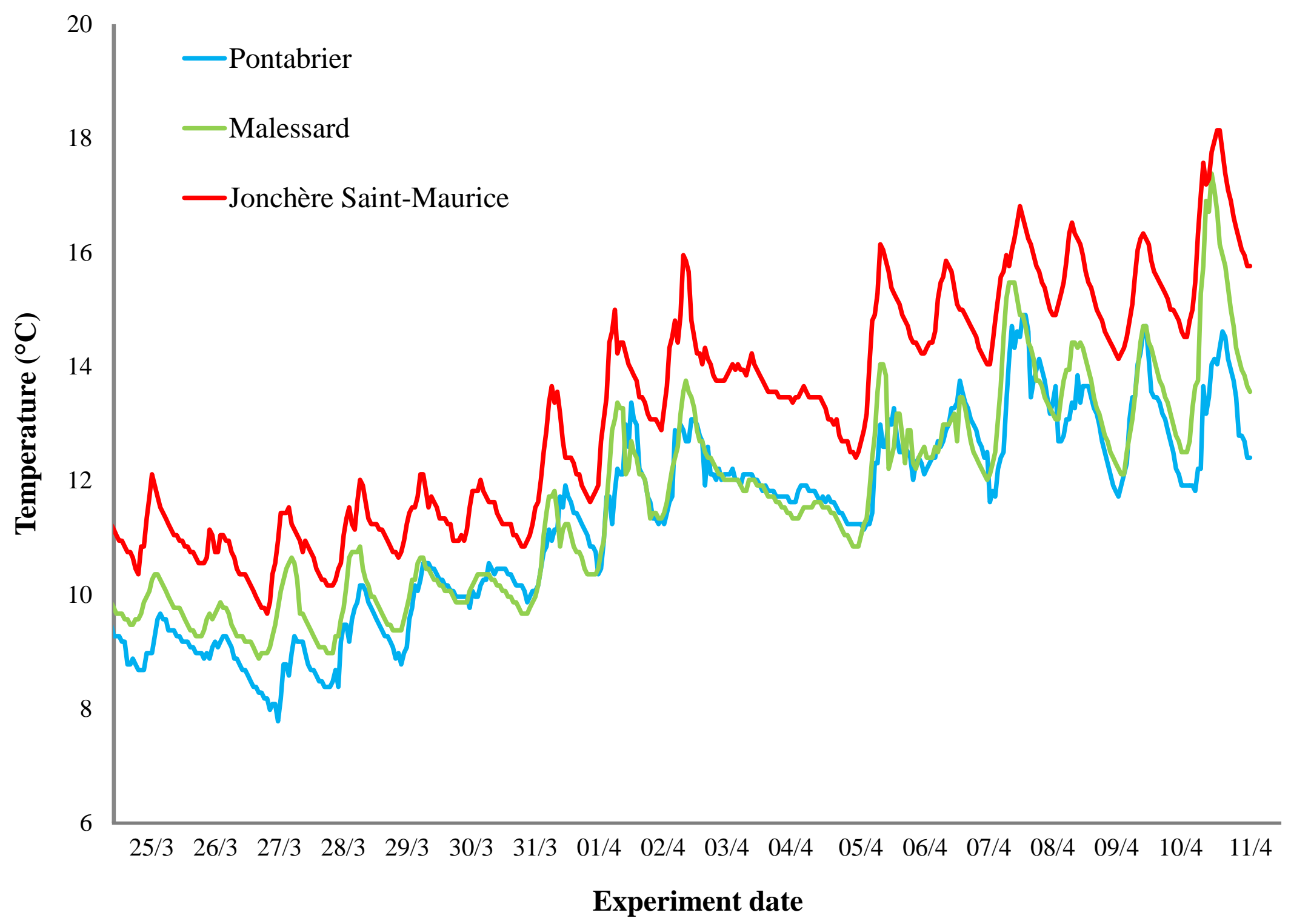




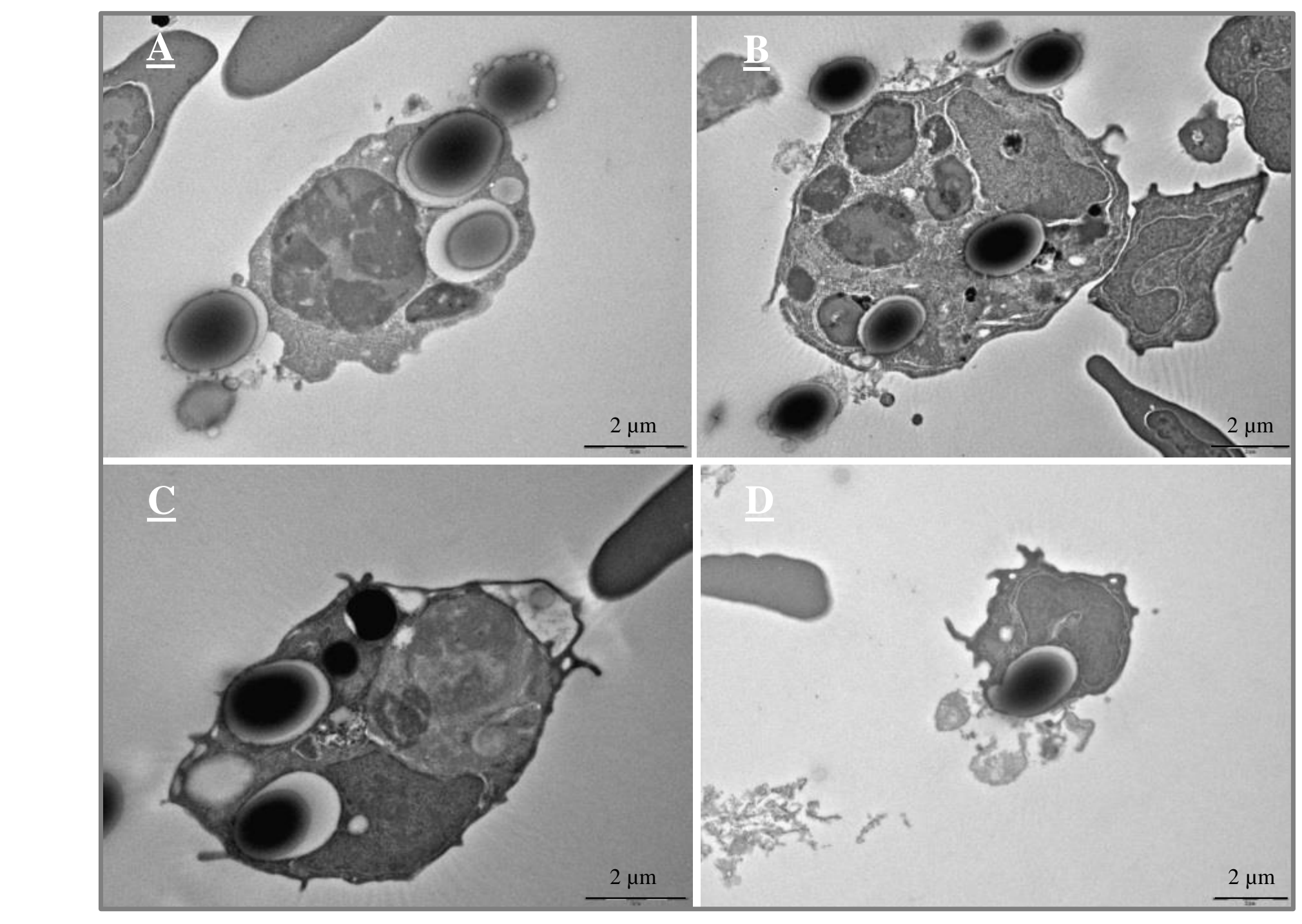




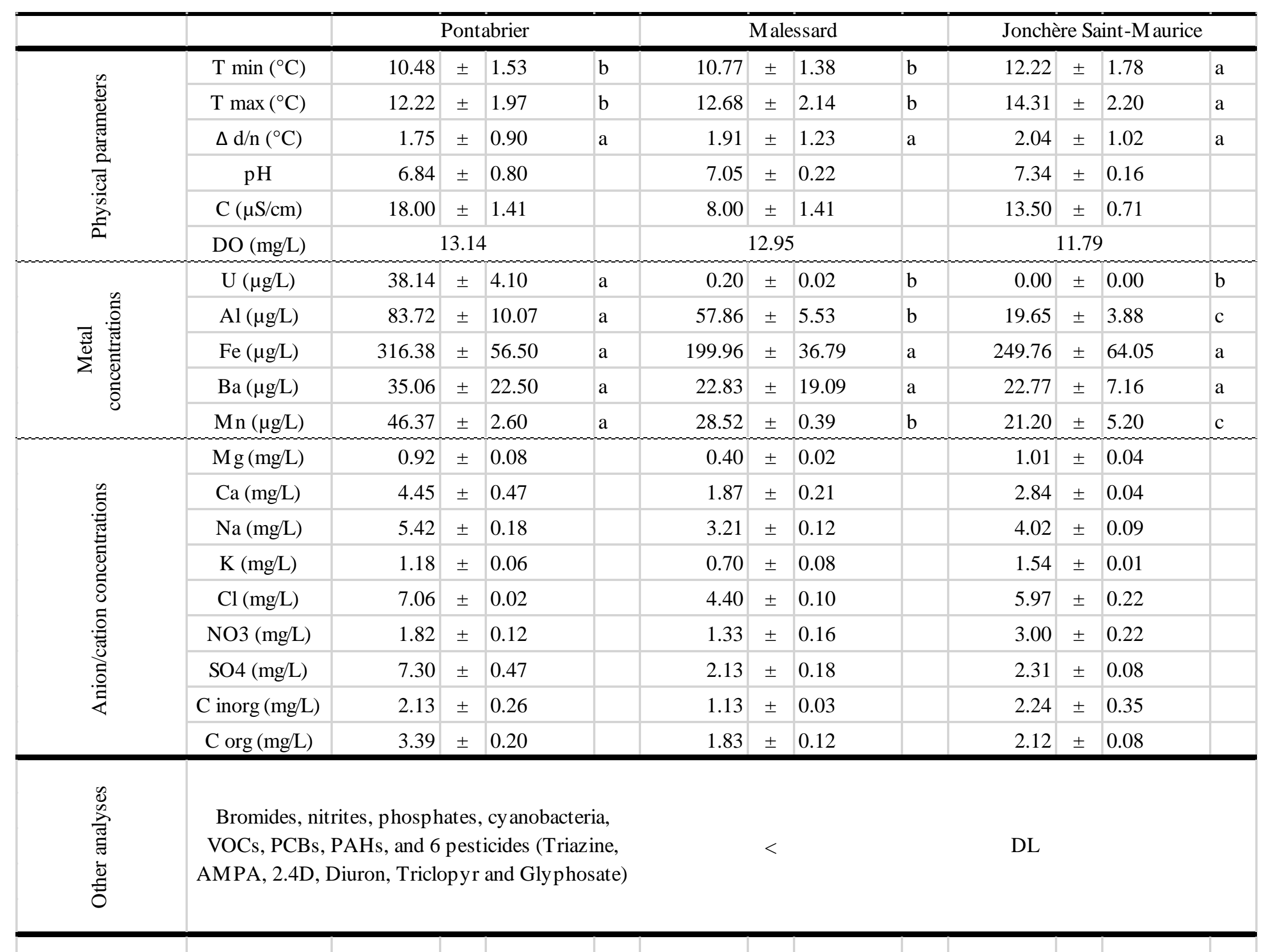




\section{Table 2 :}

\begin{tabular}{|c|c|c|c|c|c|c|c|c|c|c|c|c|c|}
\hline \multirow{2}{*}{\multicolumn{2}{|c|}{ Biomarkers }} & \multicolumn{6}{|c|}{ PBS } & \multicolumn{6}{|c|}{ LPS } \\
\hline & & \multicolumn{2}{|l|}{ Pontabrier } & Malessard & \multicolumn{3}{|c|}{ Jonchère Saint-Maurice } & \multicolumn{2}{|l|}{ Pontabrier } & \multicolumn{2}{|l|}{ Malessard } & \multicolumn{2}{|l|}{ Jonchère Saint-Maurice } \\
\hline \multirow{2}{*}{ Biometric data } & K & $0.83 \pm 0.02$ & $\mathrm{~b}$ & $0.97 \pm 0.03$ & $\mathrm{a}$ & $0.89 \pm 0.02$ & $\mathrm{ab}$ & $0.83 \pm 0.02$ & $\mathrm{~b}$ & $0.92 \pm 0.01$ & $\mathrm{a}$ & $0.91 \pm 0.03$ & $\mathrm{a}$ \\
\hline & HSI & $4.25 \pm 0.19$ & a & $4.14 \pm 0.25$ & $\mathrm{a}$ & $3.96 \pm 0.23$ & $\mathrm{a}$ & $4.48 \pm 0.25$ & $\mathrm{a}$ & $4.51 \pm 0.16$ & $\mathrm{a}$ & $3.99 \pm 0.28$ & a \\
\hline \multirow{8}{*}{ Immune capacities } & Necrosis (\%) & $4.86 \pm 0.60$ & $\mathrm{~b}$ & $6.64 \pm 0.58$ & $\mathrm{a}$ & $7.98 \pm 0.84$ & $\mathrm{a}$ & $5.99 \pm 0.49$ & $\mathrm{~b}$ & $7.16 \pm 0.43$ & $\mathrm{~b}$ & $9.58 \pm 0.75$ & $\mathrm{a}$ \\
\hline & Apoptosis (\%) & $9.89 \pm 0.84$ & a & $13.02 \pm 1.22$ & $\mathrm{a}$ & $8.20 \pm 0.96$ & $\mathrm{a}$ & $13.08 \pm 0.76$ & $\mathrm{a}$ & $15.13 \pm 1.28$ & $\mathrm{a}$ & $12.62 \pm 0.74$ & $\mathrm{a}$ \\
\hline & Lympho (\%) & $86.21 \pm 1.36$ & a & $86.37 \pm 1.09$ & a & $85.10 \pm 1.07$ & a & $85.39 \pm 0.91$ & a & $83.74 \pm 0.85$ & $\mathrm{a}$ & $82.69 \pm 0.80$ & $\mathrm{a}$ \\
\hline & LMI (FU) & $176.40 \pm 5.51$ & $\mathrm{~b}$ & $238.80 \pm 7.77$ & $\mathrm{a}$ & $150.75 \pm 5.31$ & $\mathrm{c}$ & $179.07 \pm 4.50$ & $\mathrm{~b}$ & $247.44 \pm 5.71$ & $\mathrm{a}$ & $148.29 \pm 6.65$ & $\mathrm{c}$ \\
\hline & $\operatorname{Pg}(\%)$ & $7.43 \pm 0.20$ & $\mathrm{a}$ & $7.97 \pm 0.40$ & $\mathrm{a}$ & $7.86 \pm 0.30$ & a & $7.95 \pm 0.17$ & $\mathrm{~b}$ & $7.97 \pm 0.23$ & $\mathrm{~b}$ & $\mathbf{9 . 4 0} \pm 0.19$ & $\mathrm{a}$ \\
\hline & ROS b. (FU) & $4.83 \pm 0.28$ & a & $3.33 \pm 0.15$ & $\mathrm{~b}$ & $2.67 \pm 0.26$ & b & $4.28 \pm 0.47$ & $\mathrm{a}$ & $3.34 \pm 0.47$ & $\mathrm{ab}$ & $2.86 \pm 0.32$ & $\mathrm{~b}$ \\
\hline & ROS a. (FU) & $3.46 \pm 0.20$ & a & $4.34 \pm 0.40$ & $\mathrm{a}$ & $3.74 \pm 0.42$ & $\mathrm{a}$ & $3.88 \pm 0.38$ & $\mathrm{a}$ & $5.60 \pm 1.44$ & $\mathrm{a}$ & $4.00 \pm 0.43$ & $\mathrm{a}$ \\
\hline & SI & $0.73 \pm 0.04$ & $\mathrm{~b}$ & $1.29 \pm 0.06$ & a & $1.39 \pm 0.08$ & a & $0.98 \pm 0.08$ & $\mathrm{~b}$ & $1.53 \pm 0.10$ & $\mathrm{a}$ & $1.41 \pm 0.05$ & $\mathrm{a}$ \\
\hline \multirow{7}{*}{ Oxidative stress } & $\mathrm{Gr}$ (U/g prot) & $2.25 \pm 0.51$ & $a b$ & $2.88 \pm 0.21$ & $\mathrm{a}$ & $1.86 \pm 0.23$ & $\mathrm{~b}$ & $2.16 \pm 0.45$ & a & $2.39 \pm 0.20$ & $\mathrm{a}$ & $1.45 \pm 0.34$ & a \\
\hline & GPx (U/g prot) & $63.33 \pm 14.36$ & a & $62.55 \pm 13.82$ & a & $32.06 \pm 11.86$ & a & $57.60 \pm 11.00$ & a & $85.94 \pm 17.13$ & $\mathrm{a}$ & $23.73 \pm 6.03$ & $\mathrm{a}$ \\
\hline & $\mathrm{GSH}(\mu \mathrm{mol} / \mathrm{g}$ prot $)$ & $16.71 \pm 0.99$ & a & $15.26 \pm 0.88$ & $\mathrm{a}$ & $10.75 \pm 0.76$ & b & $14.05 \pm 0.71$ & $\mathrm{a}$ & $11.29 \pm 0.80$ & $\mathrm{~b}$ & $10.79 \pm 0.83$ & $\mathrm{~b}$ \\
\hline & GST (U/g prot) & $2,384.95 \pm 131.77$ & a & $2,073.16 \pm 90.21$ & $\mathrm{ab}$ & $1,840.88 \pm 99.22$ & b & $\mathbf{1 , 9 0 9 . 6 9} \pm 91.43$ & $\mathrm{a}$ & $1,785.13 \pm 82.39$ & $\mathrm{a}$ & $1,510.43 \pm 72.40$ & $\mathrm{~b}$ \\
\hline & CAT (U/g prot) & $553,340.63 \pm 19,3783.60$ & a & $276,864.24 \pm 64,217.19$ & $\mathrm{a}$ & $431,742.28 \pm 78,553.05$ & a & $691,091.49 \pm 120714.39$ & a & $315,094.70 \pm 98235.02$ & $\mathrm{~b}$ & $222,348.64 \pm 59622.70$ & $\mathrm{~b}$ \\
\hline & SOD (U/g prot) & $1,168.35 \pm 83.02$ & $\mathrm{a}$ & $1,041.26 \pm 70.54$ & $\mathrm{ab}$ & $845.49 \pm 123.74$ & b & $1,104.94 \pm 68.45$ & $\mathrm{a}$ & $1,016.54 \pm 81.71$ & $\mathrm{a}$ & $723.22 \pm 48.87$ & $\mathrm{~b}$ \\
\hline & TBARS (FU) & $20,269.97 \pm 939.24$ & a & $9,994.83 \pm 696.19$ & $\mathrm{~b}$ & $9,589.20 \pm 505.26$ & b & $12,708.63 \pm 966.25$ & a & $9,399.23 \pm 571.78$ & b & $11,481.77 \pm 684.64$ & $\mathrm{ab}$ \\
\hline DNA damage & DNA $(\%)$ & $10.09 \pm 1.61$ & $\mathrm{~b}$ & $10.98 \pm 1.99$ & $\mathrm{ab}$ & $15.76 \pm 1.83$ & a & $11.82 \pm 1.21$ & $\mathrm{~b}$ & $21.04 \pm 4.73$ & $\mathrm{ab}$ & $25.96 \pm 5.23$ & $\mathrm{a}$ \\
\hline
\end{tabular}




\begin{tabular}{|c|c|c|c|c|}
\hline \multirow{2}{*}{\multicolumn{2}{|c|}{ Biomarkers }} & \multicolumn{3}{|c|}{ Two-way ANOVA ( $p$-value) } \\
\hline & & Pond & Injection & Pond $\times$ Injection \\
\hline \multirow{2}{*}{ Biometric data } & $\mathrm{K}$ & $*$ & & \\
\hline & HSI & & & \\
\hline \multirow{8}{*}{ Immune capacities } & Necrosis & $* * *$ & $\bullet$ & \\
\hline & Apoptosis & & $* *$ & \\
\hline & Lympho & & & \\
\hline & LMI & $* * *$ & & \\
\hline & $\mathrm{Pg}$ & $* * *$ & $* *$ & $*$ \\
\hline & ROS b. & $* * *$ & & \\
\hline & ROS a. & & & \\
\hline & SI & $* * *$ & & \\
\hline \multirow{7}{*}{ Oxidative stress } & $\mathrm{Gr}$ & $*$ & $\bullet$ & \\
\hline & GPx & & & \\
\hline & GSH & $*$ & & $\bullet$ \\
\hline & GST & $*$ & $*$ & \\
\hline & CAT & $* *$ & & $\bullet$ \\
\hline & SOD & $* *$ & & \\
\hline & TBARS & $* *$ & $\bullet$ & $* * *$ \\
\hline DNA damage & DNA & $*$ & & \\
\hline
\end{tabular}




\begin{tabular}{|c|c|c|c|c|c|c|c|c|}
\hline \multirow{4}{*}{$\begin{array}{c}\begin{array}{c}\text { Effects of LPS } \\
\text { on biomarker }\end{array} \\
\text { Pg }\end{array}$} & \multicolumn{8}{|c|}{ Significant effect (S) or not (NS) } \\
\hline & \multicolumn{2}{|c|}{ Laboratory } & \multicolumn{2}{|c|}{ Pontabrier } & \multicolumn{2}{|c|}{ Malessard } & \multicolumn{2}{|c|}{$\begin{array}{c}\text { Jonchère Saint- } \\
\text { Maurice }\end{array}$} \\
\hline & $\lambda$ & $\mathbf{S}$ & & $x$ & & $\varnothing$ & $\lambda$ & $\mathbf{S}$ \\
\hline & $\pi$ & $\mathbf{S}$ & $\lambda$ & NS & $\pi$ & NS & $\pi$ & NS \\
\hline SI & $\nearrow$ & $\mathbf{S}$ & $\pi$ & NS & ス & NS & i & $\varnothing$ \\
\hline GSH & $y$ & $\mathbf{S}$ & $y$ & NS & $\searrow$ & NS & & $\varnothing$ \\
\hline GST & $y$ & $\mathbf{S}$ & ע & $S$ & ע & NS & ע & NS \\
\hline CAT & $\searrow$ & $\mathbf{S}$ & त & NS & & $\varnothing$ & $y$ & NS \\
\hline
\end{tabular}

